\title{
Black carbon over Mexico: the effect of atmospheric transport on mixing state, mass absorption cross-section, and $\mathrm{BC} / \mathrm{CO}$ ratios
}

\author{
R. Subramanian ${ }^{1}$, G. L. Kok ${ }^{1}$, D. Baumgardner ${ }^{2}$, A. Clarke ${ }^{3}$, Y. Shinozuka ${ }^{3}$, T. L. Campos ${ }^{4}$, C. G. Heizer ${ }^{4}$, \\ B. B. Stephens ${ }^{4}$, B. de Foy ${ }^{5}$, P. B. Voss ${ }^{6}$, and R. A. Zaveri ${ }^{7}$ \\ ${ }^{1}$ Droplet Measurement Technologies, Boulder, CO 80301, USA \\ ${ }^{2}$ Universidad Nacional Autónoma de México, Mexico City, Mexico \\ ${ }^{3}$ University of Hawaii, Honolulu, HI 96822, USA \\ ${ }^{4}$ National Center for Atmospheric Research, Boulder, CO 80305, USA \\ ${ }^{5}$ St. Louis University, St. Louis, MO 63108, USA \\ ${ }^{6}$ Smith College, Northampton, MA 01063, USA \\ ${ }^{7}$ Pacific Northwest National Laboratory, Richland, WA 99352, USA
}

Received: 11 March 2009 - Published in Atmos. Chem. Phys. Discuss.: 6 April 2009

Revised: 17 September 2009 - Accepted: 20 October 2009 - Published: 13 January 2010

\begin{abstract}
A single particle soot photometer (SP2) was operated on the NCAR C-130 during the MIRAGE campaign (part of MILAGRO), sampling black carbon (BC) over Mexico. The highest $\mathrm{BC}$ concentrations were measured over Mexico City (sometimes as much as $2 \mu \mathrm{g} / \mathrm{m}^{3}$ ) and over hillfires to the south of the city. The age of plumes outside of Mexico City was determined using a combination of HYSPLIT trajectories, WRF-FLEXPART modeling and CMET balloon tracks. As expected, older, diluted air masses had lower BC concentrations. A comparison of carbon monoxide (CO) and $\mathrm{BC}$ suggests a $\mathrm{CO}$ background of around $65 \mathrm{ppbv}$, and a background-corrected $\mathrm{BC} / \mathrm{CO}_{\text {net }}$ ratio of $2.89 \pm 0.89$ $\left(\mathrm{ng} / \mathrm{m}^{3}-\mathrm{STP}\right) / \mathrm{ppbv}$ (average \pm standard deviation). This ratio is similar for fresh emissions over Mexico City, as well as for aged airmasses. Comparison of light absorption measured with a particle soot absorption photometer (PSAP) and the SP2 BC suggests a BC mass-normalized absorption cross-section (MAC) of $10.9 \pm 2.1 \mathrm{~m}^{2} / \mathrm{g}$ at $660 \mathrm{~nm}$ (or $13.1 \mathrm{~m}^{2} / \mathrm{g} @ 550 \mathrm{~nm}$, assuming MAC is inversely dependent on wavelength). This appears independent of aging and similar to the expected absorption cross-section for aged BC, but values, particularly in fresh emissions, could be biased high due to instrument artifacts. SP2-derived BC coating indicators show a prominent thinly-coated $\mathrm{BC}$ mode over the Mexico City Metropolitan Area (MCMA), while older air masses show both thinly-coated and thickly-coated BC.
\end{abstract}

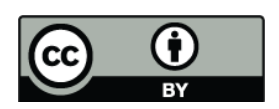

Correspondence to: R. Subramanian (randomsubu@gmail.com)
Some 2-day-old plumes do not show a prominent thicklycoated BC mode, possibly due to preferential wet scavenging of the likely-hydrophilic thickly-coated BC.

\section{Introduction}

Strongly-light absorbing carbon (LAC) particles play a major role in climate change (Jacobson, 2002; Bond, 2007; Levy et al., 2008) by absorbing solar radiation and re-radiating the energy as heat, warming the local atmosphere. LAC is emitted by combustion processes, particularly in diesel engine exhaust and biomass smoke. Hence, LAC is used as a marker of these anthropogenic processes for air quality monitoring (Subramanian et al., 2006a). The mixing state of LAC is also important from a climate change perspective, as LAC coated with non-absorbing matter such as ammonium sulfate or organic compounds can absorb up to 50\% more light than uncoated LAC (Bond et al., 2006).

Conventional filter-based techniques to measure LAC have been the subject of numerous intercomparisons (Schmid et al., 2001; Schauer et al., 2003), showing that these methods suffer from an operational definition. The term used to describe the substance is tied to the measurement technique (Bond and Bergstrom, 2006); with ther$\mathrm{mal} /$ optical techniques, the measured quantity is called elemental carbon (EC); light-absorption measurements produce BC. Hence, to avoid a method-based nomenclature, Bond and Bergstrom (2006) proposed the term LAC. Subramanian et al. (2006b) examined the biases that can cause up

Published by Copernicus Publications on behalf of the European Geosciences Union. 
to a factor-of-two difference between thermal-optical analysis protocols (Chow et al., 2001), and suggest that biases are unavoidable in any thermal protocol used to measure EC. Filter-based techniques for $\mathrm{BC}$ or particle light absorption that depend on optical observations of the filter deposit can experience problems with particulate emissions from smoldering biomass burning or other sources of liquid organic matter (Subramanian et al., 2007).

The single particle soot photometer (SP2, Droplet Measurement Technologies, Boulder, Colorado, USA) is a laser-induced incandescence instrument that detects particles which absorb light (at the laser wavelength of $1064 \mathrm{~nm}$ ), are refractory, and incandesce (Stephens et al., 2003). Certain metals can also meet these criteria, but such non-LAC particles can be filtered by monitoring their incandescence temperature (Schwarz et al., 2006), which is different from that of LAC. Since the incandescent signal is proportional to the incandescing mass, the SP2 is a true-mass detector without the problem of operationally-defined measurements experienced with conventional filter-based absorption (BC) or thermal (EC) techniques. Further, given the properties of this measured quantity - refractory, strongly-light absorbing (absorbs light even in the infra-red, unlike organic carbon, Sun et al., 2007), but independent of assumptions about the absorption per unit mass and wavelength dependence of the absorption - the SP2 measurements are closer to LAC than the previously-discussed thermal or optical techniques. However, we continue to refer to the SP2 data as BC in this paper, in keeping with the convention established by earlier SP2 studies (Schwarz et al., 2006; Moteki et al., 2007).

Other issues with conventional filter-based approaches to measuring $\mathrm{BC}$ include an inability to determine the mixing state of $\mathrm{BC}$, and relatively high detection limits that increase sampling times. The latter is particularly important for aircraft measurements that require fast time resolution. Since the SP2 measures individual particles, it has a much lower detection limit than conventional filter-based measurements, allowing for highly time-resolved data collection of concentrations as low as a few $\mathrm{ng}-\mathrm{BC} / \mathrm{m}^{3}$. An added advantage is the ability to evaluate the mixing state of $\mathrm{BC}$ using a light scattering detector also included in the SP2 (Moteki and Kondo, 2007).

During the recent Megacity Impacts on Regional and Global Environment (MIRAGE) study, part of the larger Megacity Initiative: Local and Global Research Observations (MILAGRO) campaign, the SP2 was deployed on the NSF/NCAR C-130 aircraft. Black carbon measurements were made on ten C-130 flights over the Mexico City basin and other regions of Mexico including the Yucatan peninsula, and offshore locations. Events sampled included fresh city emissions, biomass fires, as well as 1- and 2-day-old air masses transported from Mexico City. The flights usually included passes over three ground sites called T0, T1 and T2. A comprehensive description and the rationale for selecting these ground sites is summarized by Fast et al. (2007). Briefly, prior to the study, the MILAGRO modeling working group determined that during March, Mexico City pollutants are transported northeastward 20-30\% of the time, with no preferred direction for the remaining period. Fresh pollutants emitted in the Mexico City metropolitan area were sampled over and at the T0 ground site $\left(19.489^{\circ} \mathrm{N} / 99.148 \mathrm{~W}\right)$, located at the northern edge of the city. T1 $(19.703 \mathrm{~N} / 98.982 \mathrm{~W})$ is $29 \mathrm{~km}$ northeast of $\mathrm{T} 0$, and experiences a mixture of fresh and aged pollutants. When winds are from the southwest, the MCMA air mass is transported over T2 $(20.011 \mathrm{~N} / 98.906 \mathrm{~W})$, which is $63 \mathrm{~km}$ northeast of $\mathrm{T} 0$, after aging for a few hours depending on the wind speed. Thus, we can look at aerosol aging within a few hours of emission by sources in and around Mexico City.

This paper focuses on measurements in significant pollution layers encountered during the flights on 18, 19, 22 and 23 March (research flight numbers 6, 7, 8 and 9 respectively; see http://catalog.eol.ucar.edu/milagro/missions/ missions.html); the flight paths are shown in Fig. 1. The age of plumes outside of Mexico City was determined using a combination of HYSPLIT trajectories, WRF-FLEXPART modeling and Controlled Meteorological (CMET) balloon tracks. These air masses will be used to study the effects of aging during atmospheric transport on $\mathrm{BC}$ mixing state, $\mathrm{BC}$ to carbon monoxide ratio $(\mathrm{BC} / \mathrm{CO})$, and the $\mathrm{BC}$ light absorption cross-section (MAC), determined using absorption data from a particle soot absorption photometer (PSAP).

\section{Methodology and instrument characterization}

\subsection{Instrument description}

The DMT single particle soot photometer (SP2) uses a patented technique based on excitation by a $1064 \mathrm{~nm}$ Nd:YAG intracavity laser to detect particles by scattering and/or incandescence. Scattering $(1064 \mathrm{~nm})$ and broadband $(350 \mathrm{~nm}$ to $800 \mathrm{~nm})$ and narrowband incandescence (630 to $800 \mathrm{~nm}$ ) signals are recorded at $5 \mathrm{MHz}$, with the data from each particle spanning $36 \mu$ s in 180 intervals of $0.2 \mu$ s each. Stephens et al. (2003) showed that a variety of materials, including pure metals, absorb light and incandesce. However, the dominant absorbing component of atmospheric particulate matter is BC (Rosen et al. 1978). Furthermore, the ratio of the incandescence signals from the broadband and narrowband detectors, proportional to the vaporization temperature, can be used to identify the type of the incandescing particle, as metals and $\mathrm{BC}$ have different incandescence temperatures (Schwarz et al., 2006). More details, a schematic and further characterization of the SP2 are provided by Schwarz et al. (2006), Moteki and Kondo (2007), and Baumgardner et al. (2007). An intercomparison of the SP2 with other methods of BC measurement is reported by Slowik et al. (2007).

For the MIRAGE campaign, the sample flow recorded during ascents and descents was not the actual flow, an issue 
Table 1. Summary of major episodes encountered during the four MIRAGE flights, with plume age estimated using WRF-FLEXPART modeling, CMET balloons and HYSPLIT trajectory analysis.

\begin{tabular}{|c|c|c|c|c|}
\hline Pollution event & $\begin{array}{l}\text { Altitude } \\
\text { (km m.s.l.) }\end{array}$ & $\begin{array}{l}\mathrm{BC}\left(\mathrm{ng} / \mathrm{m}^{3}-\mathrm{STP}\right) \\
\text { Average } \pm \mathrm{SD} \text { (low-high) }\end{array}$ & $\begin{array}{l}\mathrm{BC} / \Delta \mathrm{CO}\left(\mathrm{ng} / \mathrm{m}^{3}-\right. \\
\mathrm{STP} / \mathrm{ppbv})\end{array}$ & $\begin{array}{l}\text { BC MAC at } \\
660 \mathrm{~nm}\left(\mathrm{~m}^{2} / \mathrm{g}\right)\end{array}$ \\
\hline \multicolumn{5}{|c|}{ Flight date: 18 March 2006} \\
\hline \multicolumn{5}{|l|}{ Fresh emissions over T0 } \\
\hline 22:41-22:47 UTC & 2.7 & $385 \pm 87(243-533)$ & $2.37 \pm 0.93$ & $\mathrm{~N} / \mathrm{A}^{\mathrm{b}}$ \\
\hline \multicolumn{5}{|l|}{ Fresh outflow over T2 } \\
\hline $20: 50-21: 36$ & 3.8 & $473 \pm 164(69-1018)$ & $3.54 \pm 0.92$ & $10.6 \pm 2.3$ \\
\hline 1 -day-old emissions, $22.2^{\circ} \mathrm{N}$ & & (west end of transects) & & \\
\hline 18:28-18:48 UTC & 3.5 & $194 \pm 66(82-321)$ & $3.43 \pm 0.51$ & $10.5 \pm 1.8$ \\
\hline 18:13-18:24 UTC & 3.8 & $212 \pm 66(72-333)$ & $3.22 \pm 0.44$ & $11.8 \pm 2.4$ \\
\hline \multicolumn{5}{|l|}{ 2-day-old emissions, $22.2^{\circ} \mathrm{N}$} \\
\hline 16:36-17:12 UTC & 4.1 & $221 \pm 104(24-451)$ & $3.26 \pm 0.69$ & $10.3 \pm 2.0$ \\
\hline \multicolumn{5}{|l|}{ Hill fires southeast of MC } \\
\hline 22:10-22:13 UTC & 4.1 & $534 \pm 362(91-1056)$ & $3.38 \pm 0.65$ & $\mathrm{~N} / \mathrm{A}^{\mathrm{b}}$ \\
\hline \multicolumn{5}{|c|}{19 March 2006} \\
\hline \multicolumn{5}{|l|}{ Fresh outflow over T2 } \\
\hline 01:05-01:16 UTC & 3.5 & $307 \pm 64(179-544)$ & $2.44 \pm 0.73$ & $13.0 \pm 0.9$ \\
\hline 01:18-01:31 UTC & 3.8 & $276 \pm 66(163-414)$ & $2.50 \pm 0.50$ & $13.9 \pm 1.8$ \\
\hline \multicolumn{5}{|l|}{ 1-day-old, $24.25^{\circ} \mathrm{N}$} \\
\hline 23:10-23:37 UTC & 3.2 & $179 \pm 41(74-292)$ & $3.22 \pm 0.42$ & $11.3 \pm 3.1$ \\
\hline $\begin{array}{l}\text { 2-day-old off Texas coast } \\
\left(27.3^{\circ} \mathrm{N}, 93.5^{\circ} \mathrm{W}\right)\end{array}$ & Profile $^{\mathrm{a}}$ & & & \\
\hline 21:32-21:37 UTC & $5.3-4.2$ & $154 \pm 91(11-332)$ & N/A & N/A \\
\hline \multicolumn{5}{|l|}{ 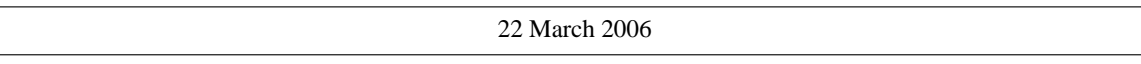 } \\
\hline \multicolumn{5}{|l|}{ Fresh emissions over T0 } \\
\hline 20:15-20:20 UTC & $2.6-3.2$ & $1100 \pm 198(842-1297)$ & $2.26 \pm 1.24$ & $\mathrm{~N} / \mathrm{A}^{\mathrm{b}}$ \\
\hline \multicolumn{5}{|l|}{ Fresh outflow over T2 } \\
\hline 18:46-18:56 UTC & 3.45 & $445 \pm 138(224-1006)$ & $3.27 \pm 0.67$ & $10.4 \pm 1.4$ \\
\hline 18:59-19:11 UTC & 3.15 & $445 \pm 162(0-744)$ & $3.14 \pm 0.75$ & $10.4 \pm 1.4$ \\
\hline \multicolumn{5}{|l|}{$\begin{array}{l}\text { 1-day-old/2-day-old } \\
\text { emissions off Nautla }\end{array}$} \\
\hline 17:32-17:49 UTC & 4.15 & $387 \pm 101(161-599)$ & $2.60 \pm 0.52$ & $10.8 \pm 1.1$ \\
\hline 17:52-18:12 UTC & 4.46 & $241 \pm 117(20-559)$ & $3.32 \pm 2.54$ & $11.6 \pm 5.6$ \\
\hline 21:25-21:37 UTC & 4.1 & $398 \pm 123(81-570)$ & $2.59 \pm 0.45$ & $11.1 \pm 2.3$ \\
\hline \multicolumn{5}{|l|}{ Hill fires/South of MC } \\
\hline 19:32-19:42 UTC & 4.1 & $704 \pm 307(287-2031)$ & $2.80 \pm 0.90$ & $12.0 \pm 3.8$ \\
\hline 19:46-20:03 UTC & 3.8 & $675 \pm 219(391-1426)$ & $3.02 \pm 0.90$ & $11.6 \pm 1.4$ \\
\hline 20:05-20:09 UTC & 3.5 & $581 \pm 63(474-756)$ & $3.24 \pm 0.43$ & $10.7(n=3)$ \\
\hline & & 23 March 2006 & & \\
\hline \multicolumn{5}{|l|}{ 1-day-old emissions over Gulf } \\
\hline 17:45-17:59 UTC & 4.6 & $159 \pm 42(11-224)$ & $2.04 \pm 0.39$ & $11.7 \pm 1.0$ \\
\hline \multicolumn{5}{|l|}{$\begin{array}{l}\text { 2-day-old emissions } \\
\text { (northern tip of Yucatan) }\end{array}$} \\
\hline 18:57-19:03 UTC & 4.9 & $122 \pm 23(77-163)$ & $2.19 \pm 0.29$ & $12.5 \pm 1.8$ \\
\hline 20:34-20:48 UTC & 4.8 & $119 \pm 31(19-183)$ & $2.19 \pm 0.47$ & $15.1 \pm 4.4$ \\
\hline Biomass burning plume & Profile $^{\mathrm{a}}$ & & & \\
\hline 19:56-20:12 UTC & $5.4-0.3$ & $419 \pm 1122(0.8-8161)$ & N/A & N/A \\
\hline
\end{tabular}

\footnotetext{
a During ascents/descents, the sample flow recorded is not the actual flow, a deficiency of the flow measurement system used in the 2006 version of the SP2. Concentrations reported here are for the descents only, are an overestimate, and are reported for reference purposes only. All other data are for level segments of the flight (altitude change $<=0.6 \mathrm{~m} / \mathrm{s}$.)

b Not enough valid data points for a robust average.
} 

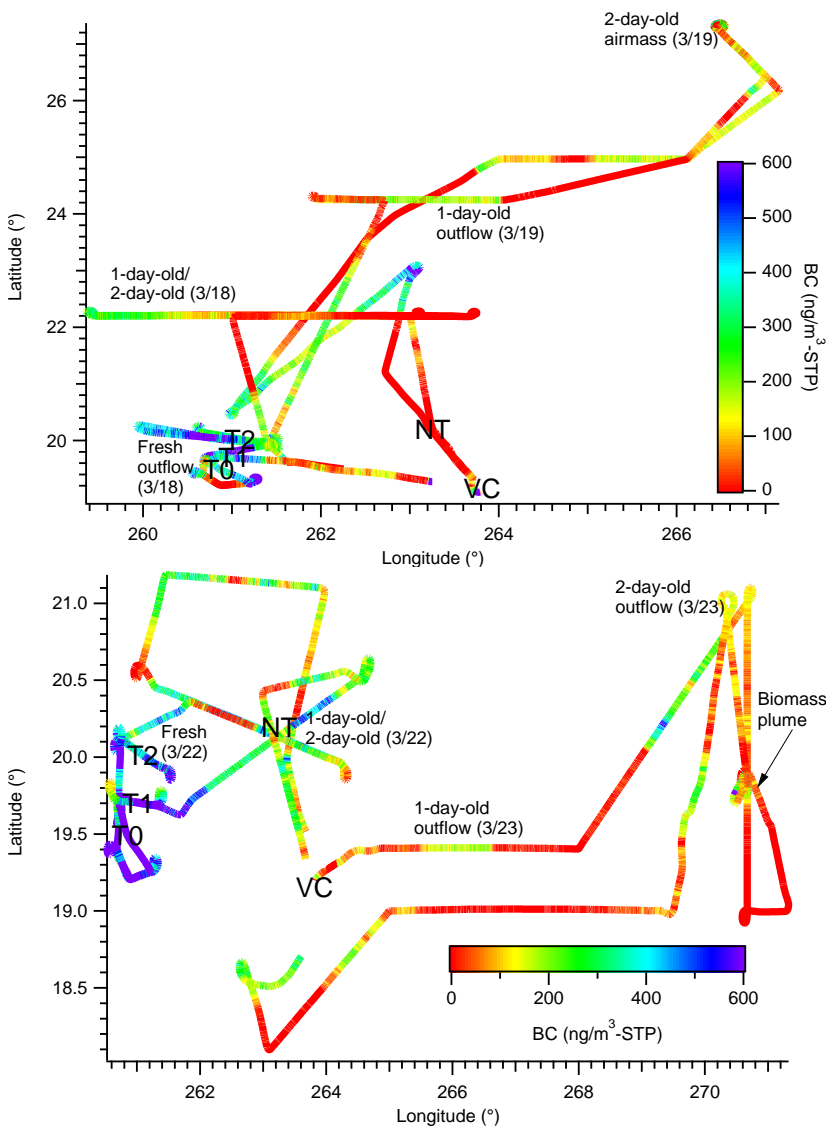

Fig. 1. Flight paths, colored by the BC mass concentration (at STP), for the four MIRAGE flights discussed in this paper. Top: 18 and 19 March; bottom: 22 and 23 March. T0, T1, T2 are ground sites described in the text (T0 is in Mexico City); VC is Veracruz, where the C130 took off and landed; NT is Nautla. The color scales are truncated at a $\mathrm{BC}$ concentration of $600 \mathrm{ng} / \mathrm{m}^{3}$ for visual clarity. Plumes labeled as described in Sect. 3 and Table 1.

with the flow measurement system used in the 2006 version of the SP2. While a discussion of vertical profiles is not included in this manuscript, only BC concentrations for a descent through the 2-day-old air mass sampled on 23 March (described later) are presented in Table 1, but are an overestimate and reported for reference purposes only. Relative abundances of thinly-coated and thickly-coated BC in this air mass (shown in Figs. 12 and 13) are unaffected as the flow error cancels out when comparing two modes from the same air mass. All other data are for level flight segments (defined as altitude changes less than $0.6 \mathrm{~m} / \mathrm{s}$ ), including the $\mathrm{BC} / \mathrm{CO}$ ratio and $\mathrm{BC}$ mass absorption cross-section time-series in Figs. 9 and 10 and Table 1.

Uncertainties in BC mass concentrations are about $\pm 20 \%$ (Baumgardner et al., 2007), but this does not include the scaling factor uncertainty described in a later section. Including the scaling factor uncertainty of $\pm 10 \%$ increases the overall uncertainty on $\mathrm{BC}$ mass during level legs to $\pm 22 \%$.

\subsection{Specificity of the SP2 for BC}

For a black body, the incandescence temperature is linearly proportional to the ratio of the broadband and narrowband incandescence signals (Moteki and Kondo, 2007). The exact relationship between these two quantities depends on the optical set-up as well as the electronic gains in the detectors. For this study, we used empirically-derived limits for the BC incandescent temperature ratio, based on the glassy carbon material used to calibrate the SP2. However, the incandescent temperature ratio could not be determined for small BC masses, where the narrowband signal was noisy. In these cases, the shape of the broadband signal was used as a filter, based on visual inspection of over 400 particles.

The incandescent temperature ratio (IR) filter, without the shape-based filter, excludes $22 \%$ of the incandescent mass detected during the 18 March flight. The peak shape-based criteria adds back $18 \%$ of the $\mathrm{BC}$ mass; these particles were excluded by the IR filter as the ratio either could not be determined or was calculated as higher than the allowed upper limit. Hence, we caution that the $\mathrm{BC}$ data reported here may be biased high by as much as $18 \%$, depending on the accuracy of the shape-based filter.

\subsection{Scaling factors}

The incandescence signal is proportional to the $\mathrm{BC}$ mass, with the incandescence peak height calibrated to $\mathrm{BC}$ mass. In the following discussions, the $\mathrm{BC}$ mass is converted to a mass-equivalent diameter (MED), assuming the density of $\mathrm{BC}$ as $1.9 \mathrm{~g} / \mathrm{cm}^{3}$ based on the recommendations of Bond and Bergstrom (2006). In case of detector saturation (which for MIRAGE occurred at $\sim 36 \mathrm{fg}$-BC or $330 \mathrm{~nm}$ BC MED), the particle mass is not calculated, though the particle is counted as part of the BC number concentration. Though the SP2 can detect a $\mathrm{BC}$ mass of $1 \mathrm{fg}$ or lower, calibrations for the MIRAGE experiment were made only down to about $3 \mathrm{fg}$ $\mathrm{BC}$, or about $145 \mathrm{~nm} \mathrm{MED}$, due to limitations of the material, Alfa glassy carbon, used to calibrate the SP2 during MIRAGE. Later calibrations with better soot proxies including Acheson Aquadag ${ }^{\mathrm{TM}}$ (a synthetic graphite) and fullerene soot have shown the linearity of the SP2 response down to $1 \mathrm{fg}-\mathrm{BC}(100 \mathrm{~nm} \mathrm{MED})$, indicating the validity of the data down to this size. The mass limitation at the upper end and the mass and count limitations at the lower end mean that the SP2 does not measure the full range of atmospheric BC. Schwarz et al. (2006) estimate that their SP2 detected about $60 \%$ of the $\mathrm{BC}$ mass and $5 \%$ of the $\mathrm{BC}$ number for the $\mathrm{BC}$ mass range from 3-300 fg/particle.

Following the approach of Schwarz et al. (2006), we fit a log-normal curve to the $\mathrm{BC}$ mass size distribution between BC mass-equivalent diameters of $145-325 \mathrm{~nm}$ (3.0 to $34 \mathrm{fg}$ $\mathrm{BC})$, extrapolated over the 10-1000 $\mathrm{nm}$ BC MED range, and obtain a $\mathrm{BC}$ mass scaling factor that is then used to determine the number scaling factor as well (Fig. 2). Changing 


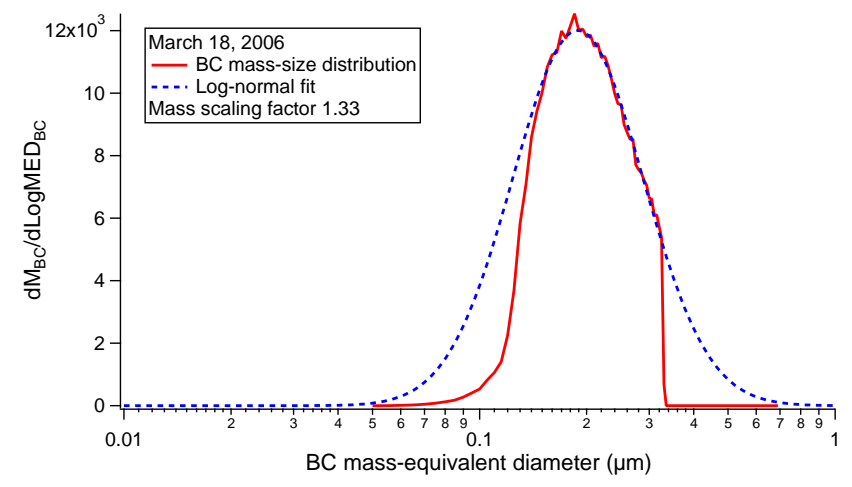

Fig. 2. To account for $B C$ masses outside the SP2 detection limits (3-36 fg), a log-normal distribution is fitted to the measured $\mathrm{BC}$ mass between 145-325 nm MED (3-34 fg-BC). Scaling factors are calculated from the ensemble $\mathrm{BC}$ mass distribution for each flight.

the diameter range over which the log-normal curve is fitted, from $130 \mathrm{~nm}$ to $170 \mathrm{~nm}$ at the lower end and from 300 to $325 \mathrm{~nm}$ at the upper end changes the mass scaling factor by less than $\pm 10 \%$. Fitting portions of the flight, such as the fresh outflow over T2 and the 1-day-old air mass sampled on 18 March does not produce scaling factors outside of the $\pm 10 \%$ uncertainty for these individual legs. For the entire 18 March flight, the SP2 appears to detect $75 \%$ of BC mass and $44 \%$ of the BC-containing particle number.

Johnson et al. (2005) observed soot aggregates larger than $1000 \mathrm{~nm}$ in Mexico City in fresh emissions; however, this refers to overall size and not to the BC mass (or BC MED) in these aggregates. The particles they observed, at sites a little farther away from the main downtown area and that could have undergone some atmospheric processing, were mostly submicron in size. Hence, our log-normal fit-based scaling factor should account for any $\mathrm{BC}$ particles that saturate the SP2 incandescence detector.

\subsection{Optical particle diameter}

The scattering signal is collected over two cones of scattered light, from $30^{\circ}-60^{\circ}$ and from $120^{\circ}-150^{\circ}$. The scattering signal in combination with Mie theory and an assumed particle composition can be used to estimate the overall particle diameter. The optical diameter calculations here assume a homogeneously-mixed BC:organosulfate mixture with $\mathrm{BC}$ volume fractions of $25 \%, 50 \%, 75 \%$ or $100 \%$, whichever is closest to the estimated particle composition (see below for a limitation on this particular SP2 dataset that renders further refinement unnecessary). The refractive index of $\mathrm{BC}$ is assumed as 1.95-0.79i based on Bond and Bergstrom (2006), while that of the non-BC coating (organic matter/ammonium sulfate) is taken as $1.48-0 \mathrm{i}$. A coreshell model does not make an appreciable difference in this calculation. The truncated collection cone and lower gain employed on the scattering detector used in the SP2 means non-incandescent particles smaller than $200 \mathrm{~nm}$ diameter (assuming a 1:1 organosulfate mixture) are not detected efficiently (if at all) in the scattering channel. An important issue with the scattering signal is that as an incandescent particle absorbs light, its temperature increases, volatilizing any nonrefractory coating. Hence, the peak scattering signal measured by the photodetector may not be representative of the original size of incandescent particles. Gao et al. (2007) employed an additional, two-element avalanche photodetector to construct a Gaussian peak based on the leading edge of the actual scattering signal to avoid this problem (called Leading Edge Optimization, LEO); however, this technique was developed after the MIRAGE campaign and cannot be used in the present analysis. Due to particle volatilization effects on the scattering signal, the scattering-based optical diameters used here are biased low, and are not used to quantify BC aging.

\subsection{Mixing state of $\mathrm{BC}$}

We can determine the mixing state of $\mathrm{BC}$ by using the separation between the scattering and incandescent peaks, which we call the incandescent lag, similar to the method employed by Moteki and coworkers (Moteki and Kondo 2007; Moteki et al., 2007). Figure 3 shows that for thinly-coated or pure $\mathrm{BC}$ particles, the scattering and incandescent peaks occur at almost the same time (incandescent lag $\sim 0$ ). Wider separations (3-4 $\mu \mathrm{s}$ ) indicate a thicker non-BC coating.

As the LEO correction could not be applied to the scattering signal in this data set, we use the scattering-based optical particle diameter only to show the relevance of the incandescent signal-based coating thickness classification. Figure 3 also shows a comparison of scattering-based coating thickness estimates (determined as described in the previous section) with the incandescent lag. Since the two parameters are reasonably correlated, we use the incandescent lag-based classification of $\mathrm{BC}$ particles as a mixing state indicator by stratifying the data as either "thinly-coated" or "thicklycoated" BC. In keeping with the definition by Moteki et al. (2007), we use $+2 \mu$ s as the limiting gap distinguishing a thinly-coated particle from a thickly-coated particle.

\subsection{Complementary measurements}

The aircraft carried an extensive suite of gas and particle instruments during the project; among them were sensors to measure $\mathrm{CO}$ and particle light absorption. The NCAR/NSF $\mathrm{C}-130 \mathrm{CO}$ vacuum UV resonance fluorescence instrument is similar to that of Gerbig et al. (1999). The MIRAGE CO data have a 3 ppbv precision, 1-second resolution, and a typical accuracy better than $+/-10 \%$ for a 100 ppbv ambient mixing ratio. The aerosol light absorption coefficient was measured using a 3-wavelength Radiance Research PSAP operated by the University of Hawaii, and is expected to be accurate to within $\pm 20 \%$ (excluding any bias due to liquid 

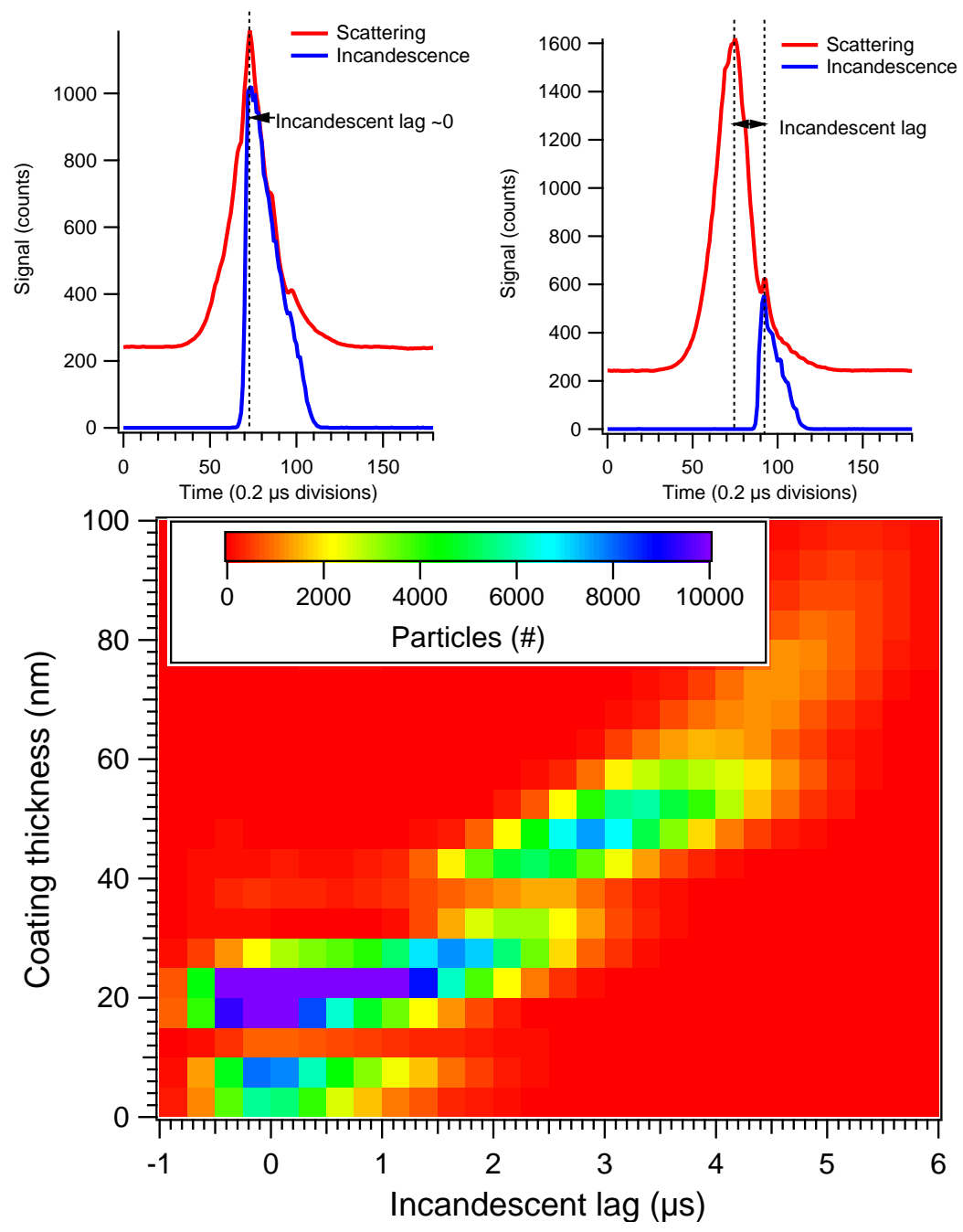

Fig. 3. The mixing state of $\mathrm{BC}$ can be determined using the separation between the incandescent and scattering peaks, or incandescent lag. An incandescent lag close to zero (top left) indicates thinly-coated BC, while larger values ( $\sim \mu \mathrm{s}$, top right) indicate thickly-coated $\mathrm{BC}$. A comparison of the incandescent lag with coating thicknesses based on the scattering signal (bottom) shows a reasonably positive correlation between the two quantities. Data from the 18 March 2006 flight.

organic matter, discussed later). Both datasets are available as part of the MILAGRO data archives (http://www-air.larc. nasa.gov/cgi-bin/arcstat-b).

\section{Determining plume age}

Based on the modeling predictions used to determine the flight path during the field campaign (Fast et al., 2007), fresh Mexico City emissions and a 1-day-old air mass sampled on 18 March were measured again on 19 March as 1-dayold and 2-day-old air masses respectively (Fig. 1). Similarly, fresh outflow and 1-day-old emissions sampled on 22 March were measured a day later on 23 March. HYSPLIT trajectories (Draxler and Rolph, 2003; Rolph, 2003),
CMET balloon tracks, and WRF modeling to determine the source and age of each plume sampled outside of the Mexico City metropolitan area are discussed below to validate the during-campaign forecasts. CMET balloons are small $(750 \mathrm{~g})$ altitude-controlled balloons that are commanded via satellite link and can remain airborne for multiple days (Voss et al., 2005; Riddle et al., 2006). (From this point on, this section uses quotation marks to identify each non-Mexico City plume until its age is validated, with CMET or WRF data).

Figure 4 shows the 18 and 19 March flight paths shown in Fig. 1, but overlaid with 24-h HYSPLIT forward and backward trajectories for each plume (computed using the REANALYSIS meteorological dataset). It also includes the CMET balloon tracks for 18 and 19 March. Figure 6 shows the HYSPLIT trajectories for the 22 and 23 March plumes. 

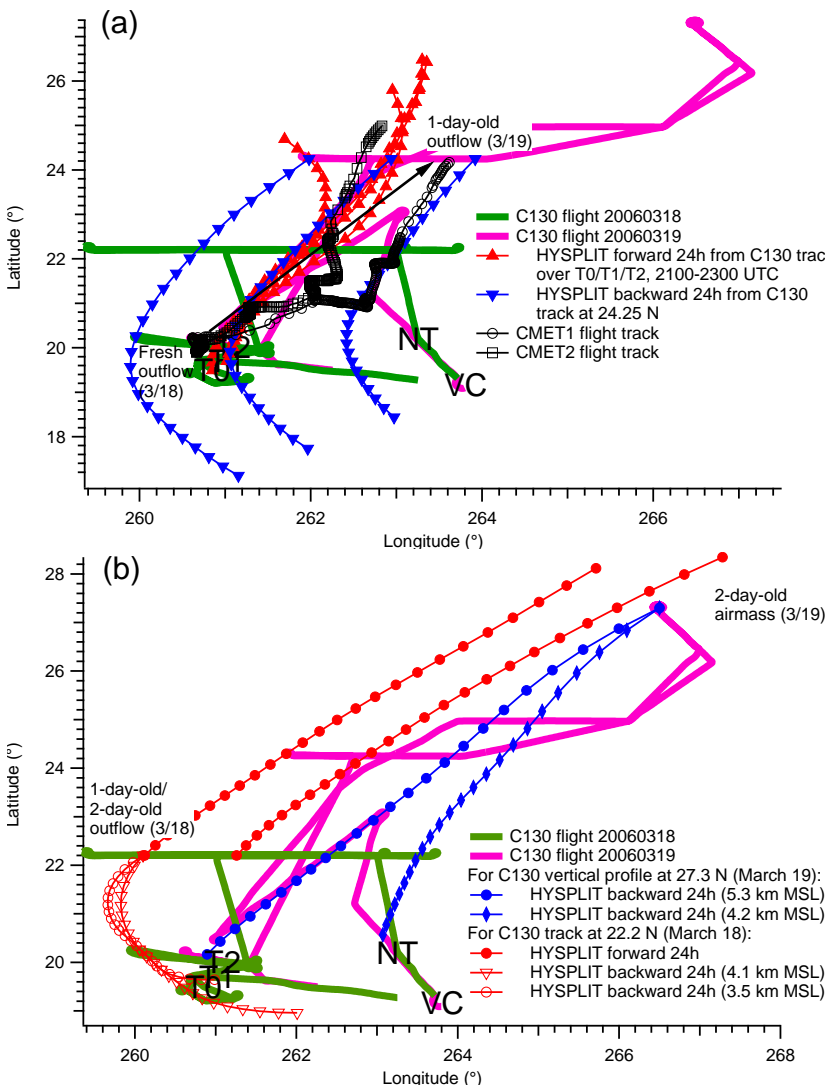

Fig. 4. HYSPLIT forward and backward trajectories for plumes encountered by the C130 flights on 18 and 19 March 2006. CMET balloon tracks that are a better indicator of the plume origin and age are also shown in (a) for the 1-day-old pollution sampled on 19 March. The CMET tracks were commanded to perform deep soundings during flight and therefore have jagged flight patterns when viewed from above.

Unfortunately, the first CMET balloon flown on 22 March was lost in a precipitation event $30 \mathrm{~min}$ after launch; due to deteriorating weather conditions, the second CMET balloon was not flown. Each of the plumes and associated trajectories are discussed below.

Lagrangian particle trajectories were simulated with high resolution gridded wind fields to estimate the age of the plumes intercepted by the C130. The Weather Research and Forecast model version 3.0.1 (WRF, Skamarock et al., 2005) was used with initial and boundary conditions from the Global Forecast System (GFS). Three domains were used with grid resolutions of $27 \mathrm{~km}$ covering the whole of Mexico, $9 \mathrm{~km}$ covering the region around Mexico City and $3 \mathrm{~km}$ covering the Mexico City basin. High resolution land use, surface albedo, vegetation fraction and land surface temperature data was obtained from the Moderate Resolution Imaging Spectroradiometer (MODIS) to improve the representation of land surface processes in the NOAH land surface scheme. Stochastic particle trajectories were calculated with
FLEXPART (Stohl et al., 2005) using WRF-FLEXPART (Fast and Easter, 2006; Doran et al., 2008). Forward trajectories were calculated based on urban $\mathrm{CO}$ emissions and were tracked at hourly intervals for $48 \mathrm{~h}$. This simulation calculates the fate of the urban plume with no deposition, scavenging or transformation processes. Simulation details and evaluation are presented in de Foy et al. (2009a). The wind fields were evaluated by calculating statistical performance metrics and by using clusters to compare the representation of flow features such as drainage or flushing winds. Particle trajectories were evaluated by comparing the results of Concentration Field Analysis and known emission fields in the basin, showing the simulations were representative of basin flow dynamics.

Particle age histograms of the urban plume by time of day at the supersites T0, T1 and T2 (de Foy et al., 2009a) showed that air masses in the basin were relatively fresh with ages usually less than 12 to $18 \mathrm{~h}$ in the basin. The age of nonMexico City plumes sampled by the C130 was determined by generating a histogram of the age of all particles in a cell containing that leg of the C130. In some cases, the domain location was adjusted to account for known discrepancies between the simulated plume location and the actual plume location. Because $\mathrm{BC}$ is relatively chemically inert, the passive tracers adequately represent the transport of $\mathrm{BC}$ out of the Mexico City basin.

\section{8-19 March plumes}

In Fig. 4(a), the HYSPLIT trajectories suggest that the age of the 19 March "1-day-old" plume at $24.25^{\circ} \mathrm{N}$ is shorter than one full day, and includes aerosol from a broader spatial range than just Mexico City. On the other hand, fresh emissions over T0 sampled on 18 March seem to have been transported to the western end of the 19 March C130 leg at $24.25^{\circ} \mathrm{N}$, while the 18 March outflow over T1 and T2 is suggested to be closer to the middle of this east-west leg a day later.

Long-range transport of pollutants in the Mexico City outflow over this same time period on 18-19 March was also tracked using Controlled Meteorological (CMET) balloons. The first CMET balloon (CMET1, Fig. 4a) was launched from the north end of the MCMA basin around the same time the $\mathrm{C} 130$ was flying over T0; a second CMET balloon (CMET2) was launched about $1.5 \mathrm{~h}$ later. The balloons performed repeated soundings as they drifted with the outflow and helped guide the 19 March C130 flight to the outflow $24 \mathrm{~h}$ later. CMET1 did a deep sounding after passing off the plateau - due to northwesterly winds lower down, its trajectory was skewed to the east. This balloon therefore shows the rough extent of the eastward dispersion of the actual outflow. CMET2 spent much of the flight at the C130 flight intercept level $(\sim 3300 \mathrm{~m})$ and is therefore a good rough indicator of the main outflow. The two CMET balloons roughly bracket 
the expected outflow at the time and altitude of the C130 intercept. The soundings from the CMET balloons result in profile data which allow reconstruction of trajectories over a range of altitudes and form the basis of a measurementdriven dispersion model. This model places the Mexico City outflow approximately between the two CMET balloon flight paths where they intersect C130 flight track (Voss et al., in preparation). In this instance, the CMET balloons were available to guide the C130. But they also show that the HYSPLIT trajectories do not capture particle dispersion, which is an important factor in determining the air parcel position and spread.

Figure $4 \mathrm{~b}$ shows HYSPLIT backward and forward trajectories for the 18 March "1-day-old" emissions at $22.2^{\circ} \mathrm{N}$, and backward trajectories for the 19 March "2-day-old" airmass sampled off the Texas Coast at $27.3^{\circ} \mathrm{N} / 93.5^{\circ} \mathrm{W}$. The western halves of the east-west legs at $22.2^{\circ} \mathrm{N}$ on 18 March were more polluted than the eastern halves, with $\mathrm{BC}$ mass concentrations about three times higher (as discussed later in Results). The $\mathrm{C} 130$ flew at three altitudes in this region: 3500 , 3800 and $4100 \mathrm{~m}$ above mean sea-level (MSL). The backward trajectory for the dominant, western plume at $22.2^{\circ} \mathrm{N}$ suggests that the airmass at $3500 \mathrm{~m}$ m.s.l. is indeed 24-h-old pollution from Mexico City, with a similar source direction from the back-trajectory at $4100 \mathrm{~m}$ m.s.l.

As for the "2-day-old" pollution measured on 19 March though the HYSPLIT back-trajectories may suggest that the aerosol at $27.3^{\circ} \mathrm{N} / 93.5^{\circ} \mathrm{W}$ might be 24 -h old from the Mexico City region, it seems likely (especially when considering particle dispersion) that the "1-day-old" plume at the western end of the east-west legs at $22.2^{\circ} \mathrm{N}$ was transported to $27.3^{\circ} \mathrm{N} / 93.5^{\circ} \mathrm{W}$ a day later, as shown by the forward trajectories from this region.

Figure 5 shows WRF-generated particle age histograms for the four plumes sampled during the 18 and 19 March flights. Figure 5a shows a 1-day-old plume at $22.2^{\circ} \mathrm{N}$ and Fig. 5b shows an aged, 2-day old plume aloft at the same location. Note that the simulated 1-day-old plume is too far to the east compared with actual measurements. While the error in the simulated plume direction was greater on this occasion, other features of the flow were well represented and suggest that the transport speed and distance were accurate, as discussed in de Foy et al. (2009b). This suggests two plumes at this location at different altitudes - but with lower 1-day-old pollution showing signs of mixing with the higher 2-day-old outflow. Based on the WRF model, the lower two legs (at $3500 \mathrm{~m}$ m.s.l. and $3800 \mathrm{~m}$ m.s.l.) appear to be more in the 1-day-old pollution (similar to the HYSPLIT results, Figure $4 \mathrm{~b}$ ), while the highest leg (at $4100 \mathrm{~m}$ m.s.l.) appears to be more aged, possibly 2-day-old.

For 19 March plumes, there is simple and good agreement: Fig. $5 \mathrm{c}$ shows a 1 -day-old plume between $24-24.5^{\circ} \mathrm{N}$ (as tracked by the CMET balloons), while Fig. 5d shows a 2-day-old plume over the Gulf of Mexico, around the location of the $\mathrm{C} 130$ vertical profile at $27.3^{\circ} \mathrm{N} / 93.5^{\circ} \mathrm{W}$. These
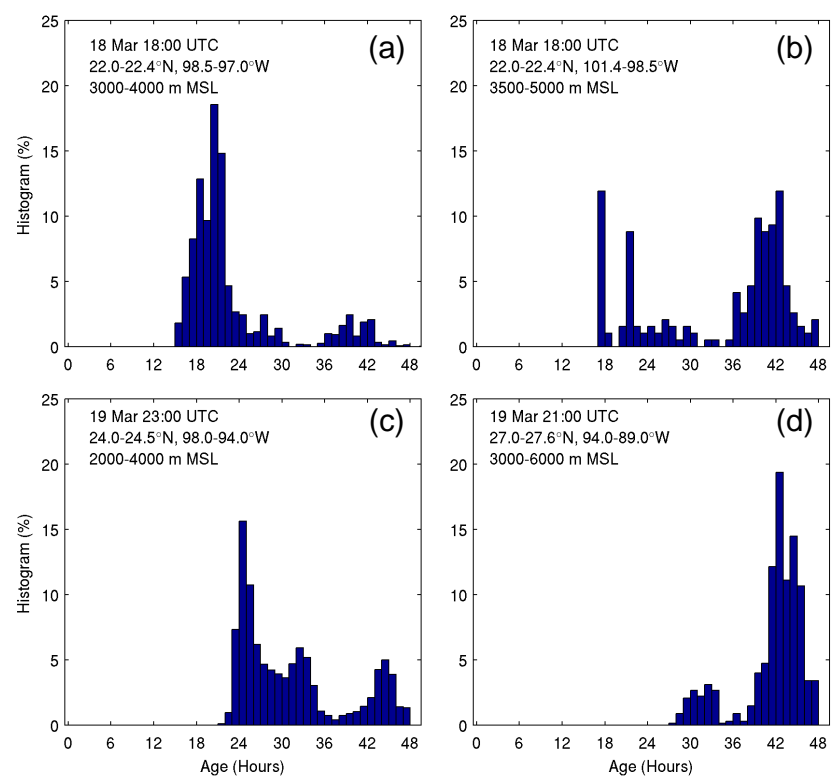

Fig. 5. Results of WRF simulations used to determine the age of the plumes sampled by the C130 on 18 and 19 March 2006. The plots show age histograms of all particles in the model cell containing the C130 flight path. (a) is 1-day-old air mass, below and mixing with 2-day-old Mexico City outflow (b), measured on 18 March. Bottom panels show the 19 March measurements of mainly 1-dayold Mexico City outflow (c) at $24.25^{\circ} \mathrm{N}$ latitude, and mostly 2-dayold aerosol off the Texas coast, over the Gulf of Mexico (d).

modeling results, along with the CMET flight tracks (Fig. 4a) and HYSPLIT trajectories (Fig. 4b), confirm the classification of these plumes as 1-day-old and 2-day-old respectively.

\section{2-23 March plumes}

Figure 6a shows HYSPLIT trajectories for the fresh plume sampled on 22 March and the "1-day-old" plume captured on 23 March by the C130. HYSPLIT suggests that the "1day-old" air mass might have passed over Mexico City about $18 \mathrm{~h}$ before being intercepted by the $\mathrm{C} 130$, while the fresh 22 March pollution didn't travel as far as expected from the city in $24 \mathrm{~h}$. [The backward trajectories from this location at lower altitudes are explained later.] Figure $6 \mathrm{~b}$ also shows an apparent mismatch between the 22 March "1-day-old" outflow off Nautla and the 23 March "2-day-old" air mass over the Yucatan, though as mentioned earlier, these trajectories do not account for particle dispersion. Further, a 48-h backward trajectory (see WRF results for this length of time) for the "1-day-old" plume sampled on 22 March off Nautla suggests this air mass never passed over Mexico City.

For the "1-day-old" 22 March airmass off Nautla, WRFFLEXPART simulates a double plume: a fast moving plume above and a slower moving one below, both going due east from Mexico City. There is some mixing between them 

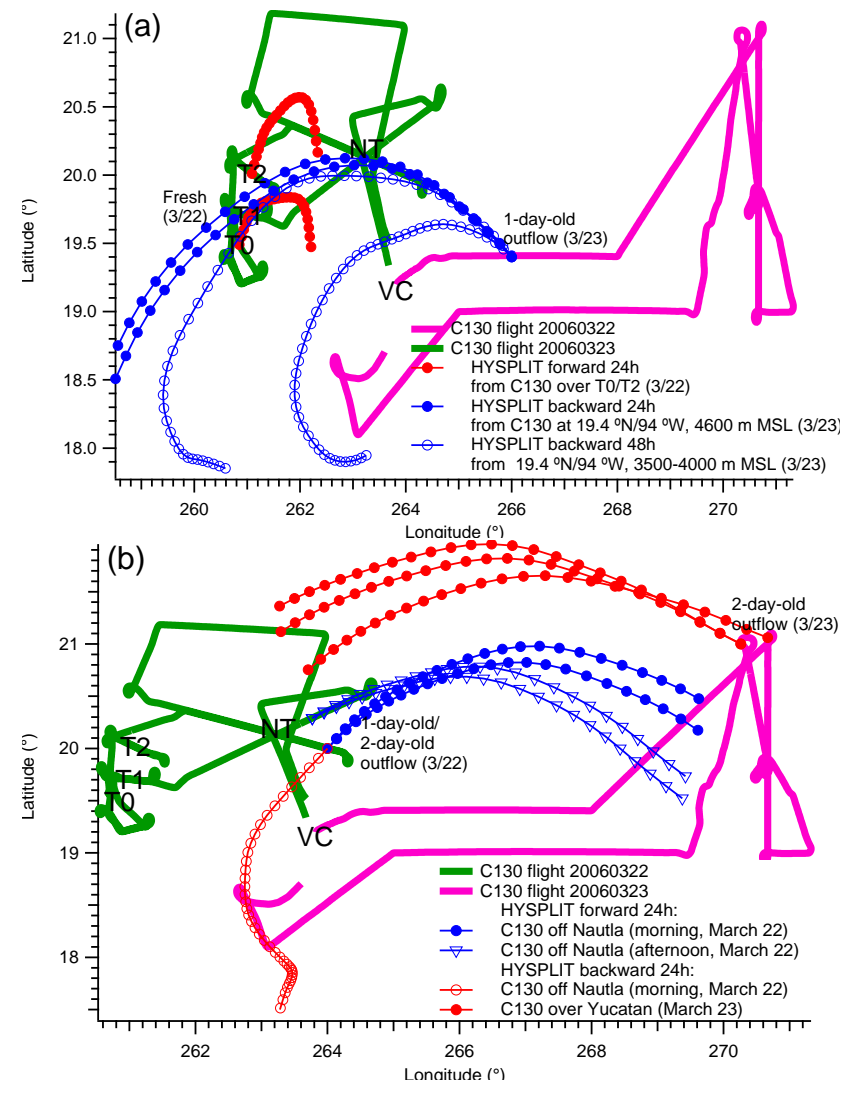

Fig. 6. HYSPLIT trajectories for the plumes encountered by the C130 during the flights on 22 and 23 March 2006. (a) shows backward trajectories from $19.4^{\circ} \mathrm{N} / 94^{\circ} \mathrm{W}$ at three altitudes for comparison with WRF-FLEXPART results, though the C130 sampled at 4600 m m.s.l.

leading to particle age histograms with two separate age peaks. This suggests that on 22 March (Fig. 7a, b) the C130 could have sampled a mixture of 1-day old and 2-day old Mexico City outflow off Nautla between $97-96^{\circ} \mathrm{W}$, although the 2-day old airmass appears to dominate closer to the latitudes (19.8-20.4 ${ }^{\circ} \mathrm{N}$ ) where the C130 sampled (Fig. 7b).

The same feature is observed on 23 March over the Gulf of Mexico and the Yucatan peninsula - relatively fresher 1-dayold pollution (Fig. 7c, e) above 2-day-old airmass (Fig. 7d, f). While the C130 leg between 17:45-17:59 UTC is at $4600 \mathrm{~m}$ m.s.1., just within the 1-day-old pollution but close to where the model separates the plumes $(4500 \mathrm{~m}$ m.s.l., Fig. 7c, d), the C130 appears to have sampled mostly 2-dayold aerosol over the Yucatan later during that flight while flying at 4800-4900 m m.s.1. (Fig. 7e, f).

For the "1-day-old" plume on 23 March over the Gulf of Mexico, WRF-FLEXPART simulates two plumes at different heights moving at different speeds. At $4600 \mathrm{~m} \mathrm{MSL}$, HYSPLIT shows an almost-1-day-old air mass $(\sim 18 \mathrm{~h}$ out of Mexico City), which is closer to the WRF-FLEXPART results for the 1-day-old plume between $4500-6000 \mathrm{~m}$ m.s.1..
However, the HYSPLIT backward 48h trajectories at lower altitudes (3500-4000 m m.s.1.) do not match with the WRFFLEXPART results - in fact, the HYSPLIT backward trajectory from $3500 \mathrm{~m}$ m.s.l. does not even pass over Mexico City, similar to the backward trajectory for the plume sampled off Nautla on 22 March.

The final classification of the plumes is based on the WRF modeling, as it better captures the complexity of atmospheric transport. To summarize, plume ages for the 22/23 March flights are a little more complex than for the 18/19 March flights. The "1-day-old" air mass off Nautla actually appears to be 2-day-old Mexico City aerosol. The plume over the Gulf of Mexico at $19^{\circ} \mathrm{N}$ could be a mixture of 1-day-old and 2-day-old air masses but appears to be 1-day-old, and the plume over the Yucatan is quite likely 2-day-old Mexico City outflow.

\section{Results}

\subsection{BC concentrations}

The MIRAGE field campaign was conducted between 331 March 2006, and used the NSF/NCAR Hercules C-130 based at Veracruz International Airport. The analysis for the study presented here is from four of the ten flights that were flown. The time histories of BC mass concentrations measured during these flights are presented in Fig. 8 as 10s averages (normalized to STP, 1 bar and $273.15 \mathrm{~K}$ ); spatial distributions (BC concentrations along the flight paths) were shown in Fig. 1.

On 18 March, the aircraft did an east-west transect at $22.2^{\circ} \mathrm{N}$, sampling 1-day-old emissions from Mexico City at multiple altitudes between $3.5-5.4 \mathrm{~km}$ above sea level (MSL). BC mass concentrations were higher at the western ends of these transects, averaging $\sim 200 \mathrm{ng} / \mathrm{m}^{3}$, while BC mass at the eastern ends averaged $\sim 60 \mathrm{ng} / \mathrm{m}^{3}$ or less. The aircraft rendezvoused with the Department of Energy (DOE) Gulfstream-1 (G1) aircraft for a parallel east-west intercomparison flight near the T2 sampling site. During this period BC concentrations were high, occasionally over $1000 \mathrm{ng} / \mathrm{m}^{3}$. Following the intercomparison, the aircraft flew over Mexico City. South of the city, the air was relatively clean with BC often below $50 \mathrm{ng} / \mathrm{m}^{3}$. Emissions from a small mountain fire were sampled southeast of Mexico City, with BC as high as $1041 \mathrm{ng} / \mathrm{m}^{3}$. The plane then flew back over T0, where BC averaged $375 \pm 77 \mathrm{ng} / \mathrm{m}^{3}$, before flying back to Veracruz. These and similar events encountered during the four flights are summarized in Table 1. 

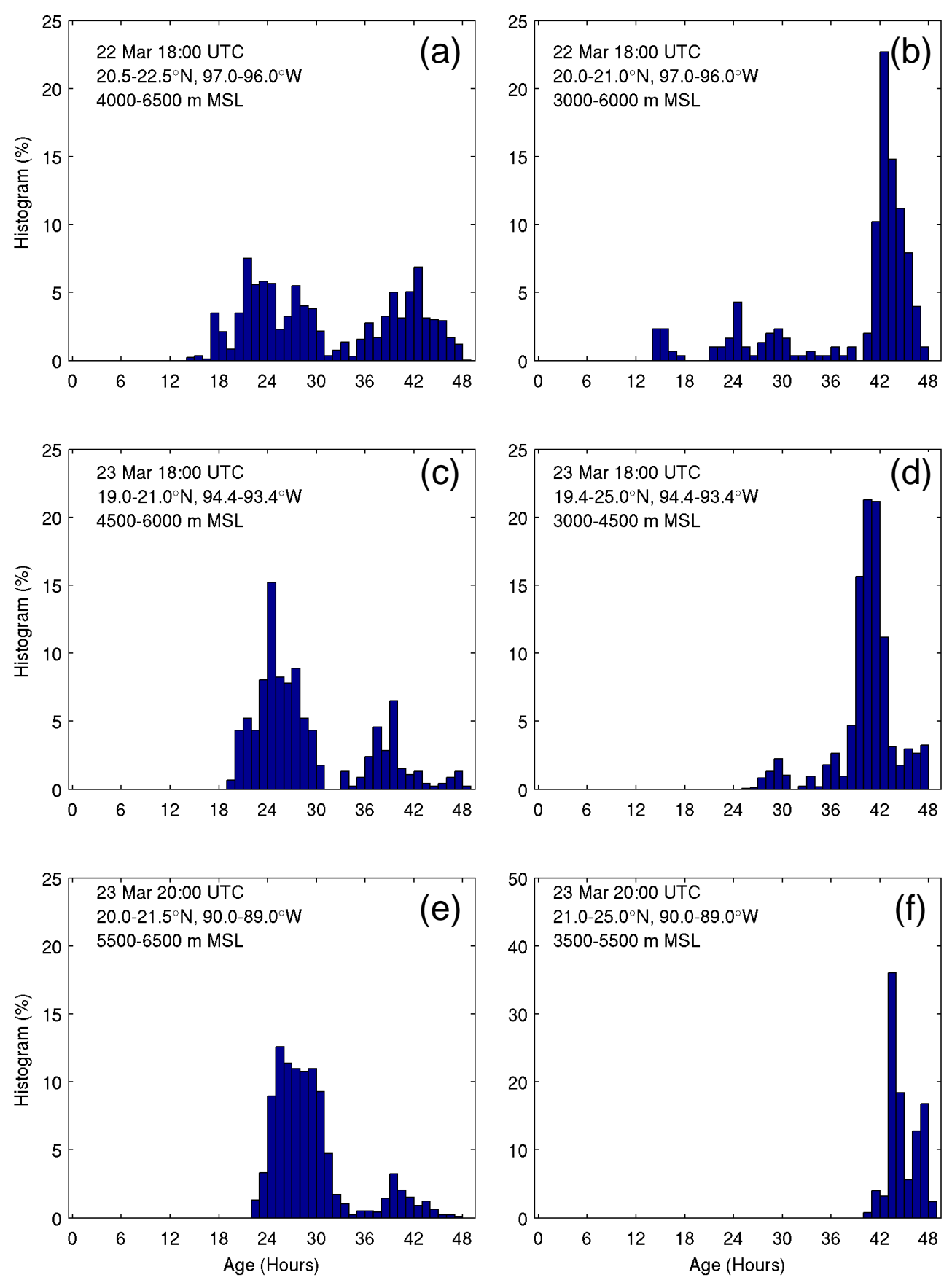

Fig. 7. WRF model results showing particle age histograms for the plumes sampled by the C130 on 22 and 23 March 2006 . (a, b) Mixture of 1-day-old and 2-day-old Mexico City outflows off the coast of Nautla, sampled 22 March. (c, d) 1-day-old air mass above 2-day-old outflow over the Gulf of Mexico on 23 March; the C130 flew at 4600 m m.s.l., between these two layers. (e, f) Same as (c, d) except over the Yucatan; in this case, the $\mathrm{C} 130 \mathrm{flew}$ at $4800 \mathrm{~m}$ m.s.l. and $4900 \mathrm{~m}$ m.s.l., in the middle of the 2-day-old outflow.

\subsection{Carbon monoxide and $\mathrm{BC}$}

Carbon monoxide (CO) and $\mathrm{BC}$ are both products of incomplete combustion, and thus indicators of combustion emissions. The $\mathrm{BC} / \mathrm{CO}$ ratio has been suggested as dependent on the source mix, for example, the fraction of heavy-duty diesels in the fleet (Kirchstetter et al., 1999), though other factors like fleet age and condition may also affect the ratio (Baumgardner et al., 2002). BC/CO ratios have also been used to estimate $\mathrm{BC}$ emissions based on $\mathrm{CO}$ emission inventories (Dickerson et al., 2002). This assumes that both BC and $\mathrm{CO}$ are conserved, so that the $\mathrm{BC} / \mathrm{CO}$ ratio is constant 


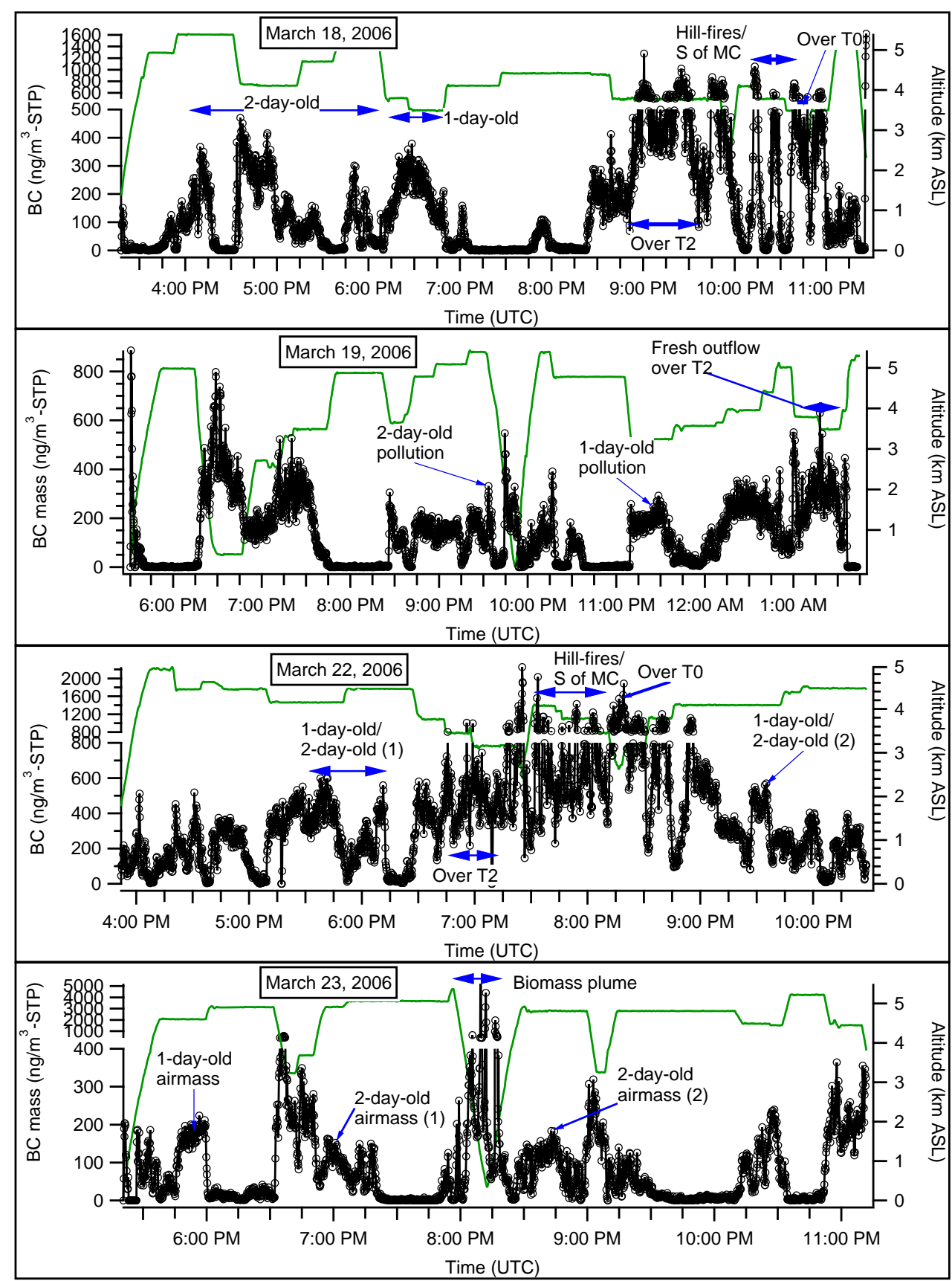

Fig. 8. BC concentrations measured by the SP2 during four flights of MIRAGE. Data are presented at standard temperature and pressure (273.15 K, 1 bar). Green lines show flight altitude.

despite atmospheric dilution, and changes in the $\mathrm{BC} / \mathrm{CO}$ ratio are due to other effects.

Figure 9 shows the $\mathrm{BC} / \mathrm{CO}$ ratios measured during the 18 and 22 March 2006 flights. Figure 9(a) shows a substantial $\mathrm{CO}$ concentration apparently not associated with $\mathrm{BC}$. This is likely the background concentration of $\mathrm{CO}$ due to the longer atmospheric lifetime of $\mathrm{CO}$ relative to $\mathrm{BC}$ - about a month in tropical regions for CO (Khalili and Rasmussen, 1990) and about a week for BC (in the absence of rain) (Ogren and Charlson, 1983). Hence, BC/CO ratios should be considered after correcting for this background. For the four flights, the CO baseline is estimated at 62 (18 and 19 March), 68 (22 March) and 65 (23 March) ppbv-CO respectively. The baseline is determined by plotting a frequency distribution of the $\mathrm{CO}$ data, and using the Gaussian mean of the lowest frequency peak as the background $\mathrm{CO}$ concentration. 

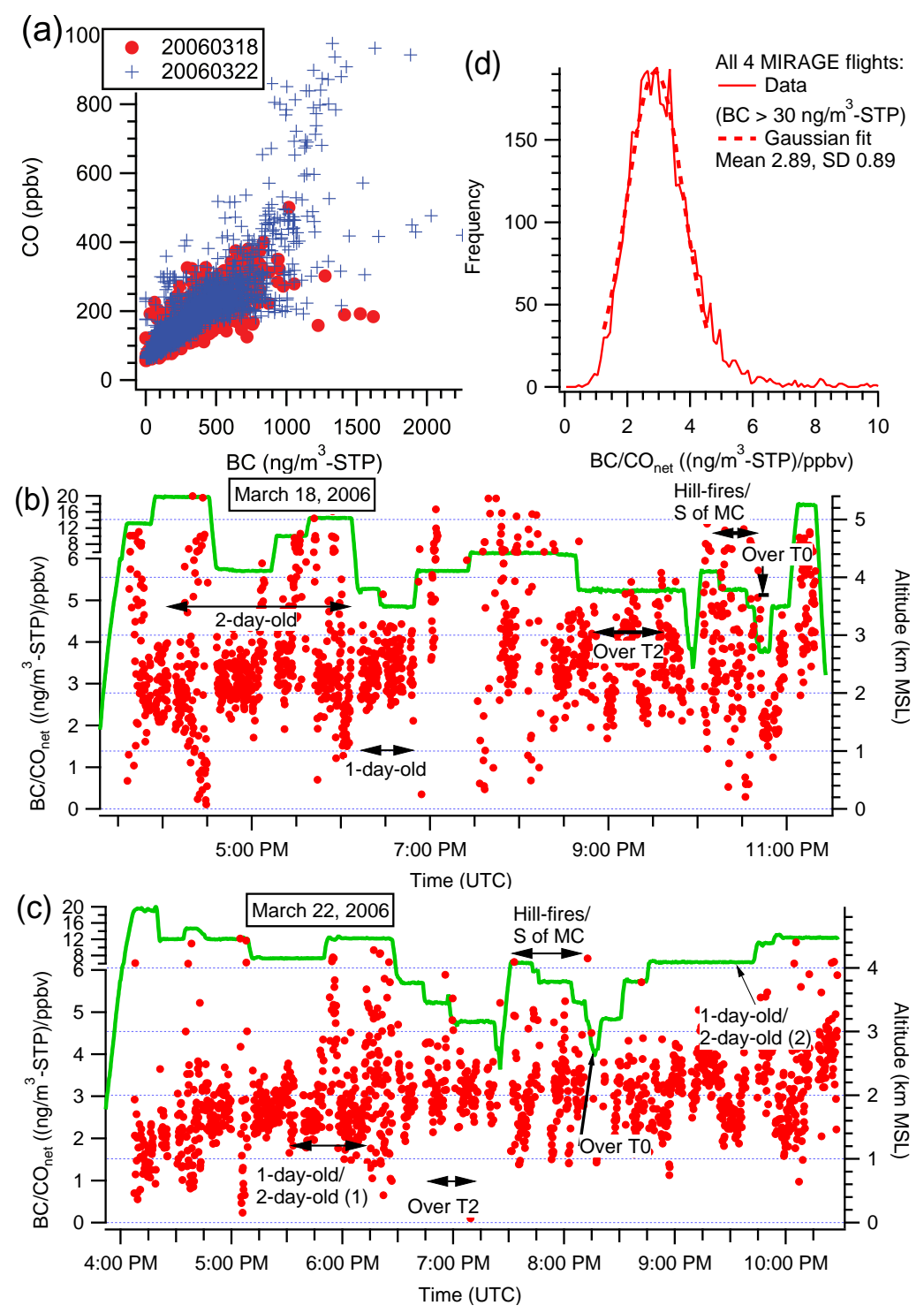

Fig. 9. BC/CO ratios during the four MIRAGE flights, with BC corrected to STP (1 bar, 273.15 K). Plot (a) shows a substantial background concentration of $\mathrm{CO}$, probably due to the longer lifetime of $\mathrm{CO}$ compared to BC. Plots (b), (c) and (d) show BC/CO $\mathrm{CH}_{\text {net }}$ ratios after correcting $\mathrm{CO}$ for an approximate background value, limited to level segments (altitude change $<=0.6 \mathrm{~m} / \mathrm{sec}$ ). Only the 18 and $22 \mathrm{March}$ data are shown as time-series for visual clarity; data from the events of all four flights are summarized in Table 1 . No significant change is seen in the $\mathrm{BC} / \mathrm{CO}_{\text {net }}$ ratio for fresh or aged air masses $(\mathrm{b}, \mathrm{c})$, with the mean $\mathrm{BC} / \mathrm{CO}_{\text {net }} 2.89\left(\mathrm{ng} / \mathrm{m}^{3}-\mathrm{STP}\right) / \mathrm{ppbv}$ for all four flights $(\mathbf{d})$.

Defining the baseline as 2 standard deviations ( +8 ppbv for 22 March) above the Gaussian mean does not make a significant difference to the event-average $\mathrm{BC} / \mathrm{CO}_{\text {net }}$ ratios in Table 1. Figures $9 \mathrm{~b}$, c present background CO-corrected $\mathrm{BC} / \mathrm{CO}_{\text {net }}$ ratios from the 18 and 22 March flights as timeseries plots, and a histogram of $\mathrm{BC} / \mathrm{CO}_{\text {net }}$ ratios from all four flights is plotted in Figure 9(d). Despite the differentlyaged air masses sampled during these flights, relatively little variation is seen in the event-average $\mathrm{BC} / \mathrm{CO}_{\text {net }}$ ratios considering the variability represented by the associated standard deviations (average SD 26\% for the events in Table 1).
The mean $\mathrm{BC} / \mathrm{CO}_{\text {net }}$ ratio (and standard deviation) for all four flights is $2.89 \pm 0.89\left(\mathrm{ng} \mathrm{m}^{-3}-\mathrm{STP}\right) / \mathrm{ppbv}$ (Fig. 9d), or $\sim 2.3 \mathrm{ng}-\mathrm{BC} / \mu \mathrm{g}-\mathrm{CO}$, with a propagated measurement uncertainty of about $\pm 25 \%$.

\subsection{Particle light absorption and BC}

BC mass concentrations measured with the SP2 are compared to the PSAP absorption measurements at $660 \mathrm{~nm}$, where interference from non-BC species is expected to be minimal (Sun et al., 2007). Figure 10 shows time-series 

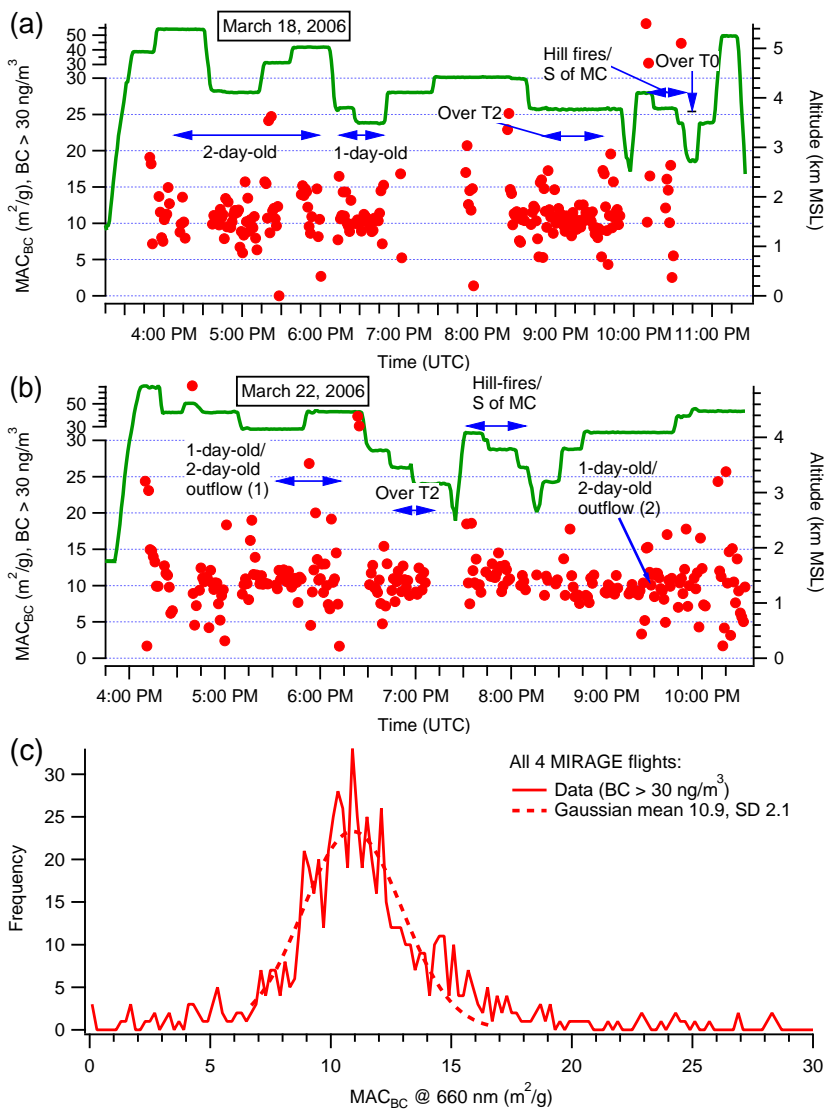

Fig. 10. Absorption cross-section of $B C$ at $660 \mathrm{~nm}$, assuming that all light absorption at this wavelength is due to BC. 1-minuteaveraged data, limited to $\mathrm{BC}$ concentrations over $30 \mathrm{ng} / \mathrm{m}^{3}$, limited to level segments (altitude change $<=0.6 \mathrm{~m} / \mathrm{s}$ ). The absorption cross-section does not vary appreciably with air mass age $(\mathbf{a}, \mathbf{b})$, with the mean absorption cross-section $10.9 \mathrm{~m}^{2} / \mathrm{g}-\mathrm{BC}$ at $660 \mathrm{~nm}$ for all four flights (c).

plots and histograms (for $\mathrm{BC}>30 \mathrm{ng} / \mathrm{m}^{3}$ ) of the $\mathrm{BC}$ massnormalized absorption cross-section (MAC) on a 1-minuteaverage basis (both the PSAP data and BC concentrations are at ambient conditions), with the average and standard deviation for each event/over the location in Table 1.

The average MAC values for the different air masses are not significantly different, for example $10.6 \pm 2.3 \mathrm{~m}^{2} / \mathrm{g}$ for fresh outflow on 18 March and $11.3 \pm 3.1 \mathrm{~m}^{2} / \mathrm{g}$ in the 1 -dayold air mass on 19 March (Table 1). This is surprising, as one might expect that with age, the non-BC coating thickness increases, which could increase the absorption cross-section by as much as 50\% (Bond et al., 2006). Hence, the MAC should be significantly lower in the fresh emissions over T0 compared to that in aged aerosol. The fire-influenced air mass sampled on 22 March has an absorption cross-section similar to the samples not directly influenced by biomass burning. A histogram of the 1-minute average BC MAC values from all four flights shows a Gaussian mean (and standard

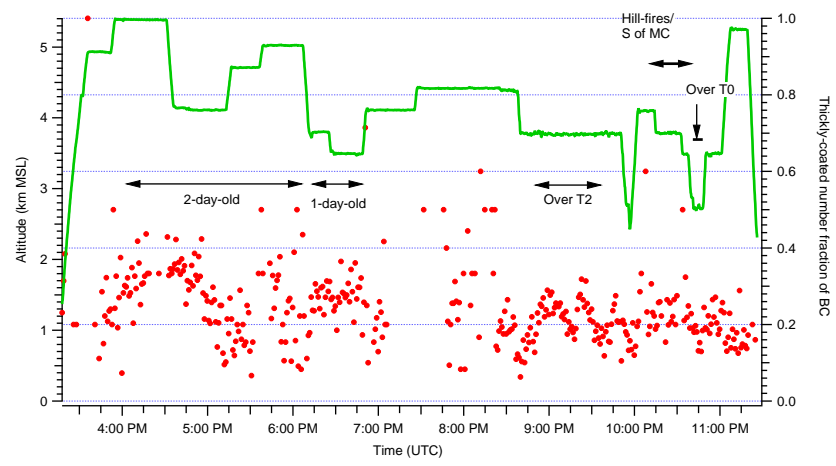

Fig. 11. Thickly-coated $B C$ number fraction for particles containing 5.3-6.3 fg-BC/particle (175-185 nm MED) for the 18 March 2006 flight.

deviation) of $10.9 \pm 2.1 \mathrm{~m}^{2} / \mathrm{g}$-BC at $660 \mathrm{~nm}$ (Fig. 10c), with a propagated measurement uncertainty of $\pm 30 \%$. In comparison, the MAC for fresh combustion soot is expected to be around $7.5 \pm 1.2 \mathrm{~m}^{2} / \mathrm{g}$ at $550 \mathrm{~nm}$, or $6.3 \mathrm{~m}^{2} / \mathrm{g}$ at $660 \mathrm{~nm}$ assuming an inverse-wavelength $\left(\lambda^{-1}\right)$ dependence (Bond and Bergstrom, 2006). Thus, our measurements of the BC MAC are about $75 \%$ higher than that expected for fresh soot, but within measurement uncertainty bounds $( \pm 30 \%)$ of the $50 \%$ increase in MAC expected for aged soot compared to fresh soot. Other possibilities are discussed in a later section.

\subsection{Evolution of BC mixing state}

Moteki et al. (2007) looked at the evolution of BC mixing state using an SP2. They presented results in terms of the fraction of BC-containing particles that is thicklycoated. Their results were focused on particles with a $\mathrm{BC}$ content of $5.4 \mathrm{fg} /$ particle $(180 \mathrm{~nm}$ MED with a BC density of $1.77 \mathrm{~g} / \mathrm{cm}^{3}$, or $176 \mathrm{~nm}$ MED at the BC density we use, $1.9 \mathrm{~g} / \mathrm{cm}^{3}$ ). Figure 11 shows a similar analysis for the 18 March MIRAGE flight, when the aircraft sampled fresh Mexico City emissions as well as 1-day-old and 2day-old outflow at $22.2^{\circ} \mathrm{N}$. Though the comparison is between 18 March fresh emissions and aged aerosol from previous days, similar aging processes should affect the Mexico City outflow from these days. For the 18 March plumes in Table 1, the thickly-coated fraction is $0.17 \pm 0.03$ over T0, $0.23 \pm 0.04$ over T2, $0.28 \pm 0.05$ in the 1 -day-old emissions at $3.5 \mathrm{~km}$ m.s.l., and $0.29 \pm 0.08$ in the 2-day-old emissions at $4.1 \mathrm{~km}$ m.s.l.. Moteki et al. (2007) found that the thicklycoated $\mathrm{BC}$ fraction increased by $2.3 \% \mathrm{~h}^{-1}$ (from 0.35 to 0.63 over $12 \mathrm{~h}$ ) over Japan, which is clearly much faster than any increase for the Mexico City plumes.

As an alternative, we compare the fresh and aged air masses sampled on 18 and 19 March and on 22 and 23 March (Fig. 1). The fresh Mexico City outflows sampled on the first day of each pair of flights were likely sampled again on the second day as described in Sect. 3; sampling of (practically) 

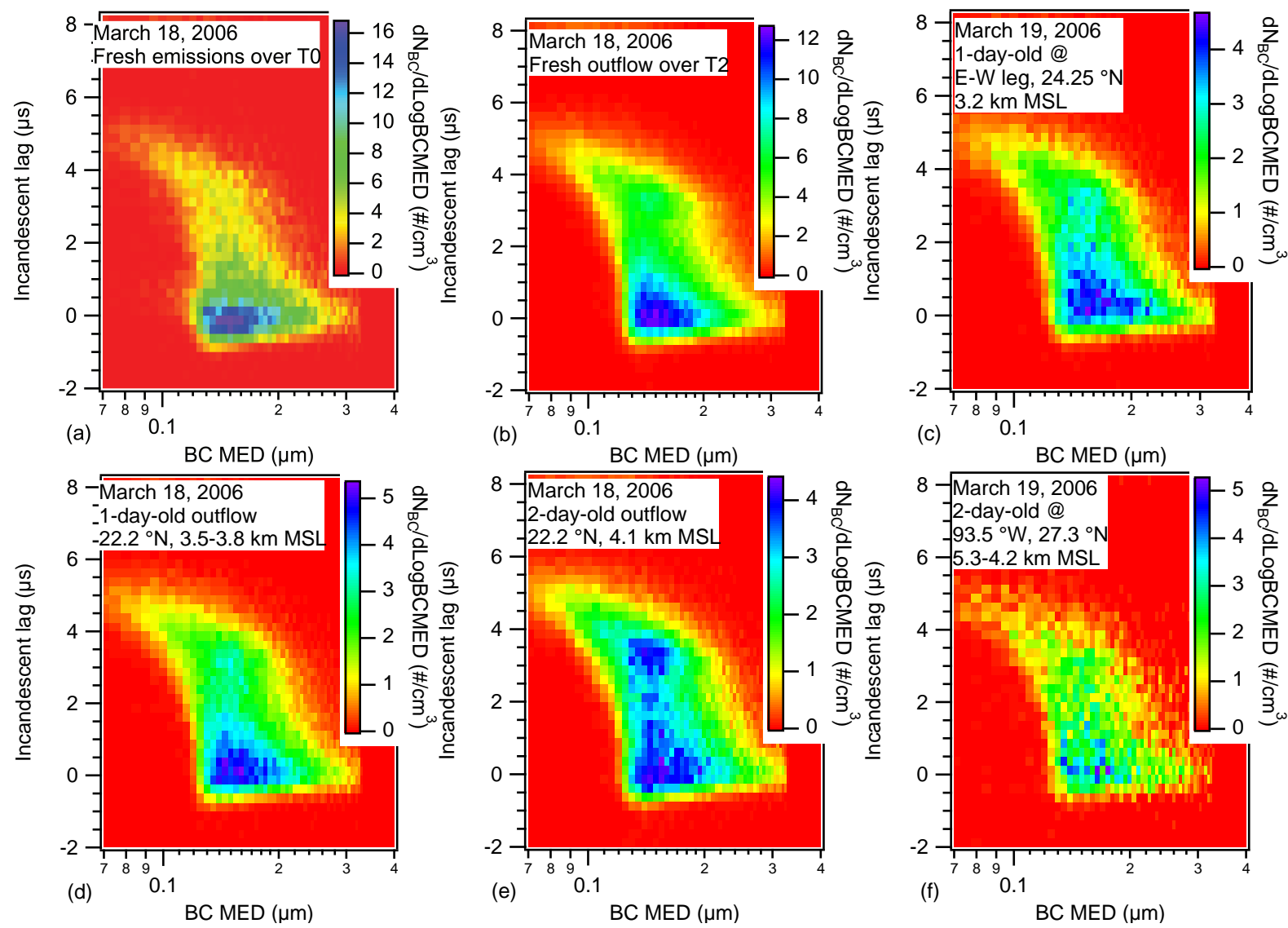

Fig. 12. Evolution of BC mixing state during transport north/northeast between 18 and 19 March 2006. The top panels show fresh emissions from Mexico City transported over T0 (a) and further north over T2 (b) on $18 \mathrm{March}$, and at $24.25^{\circ} \mathrm{N}$ a day later (c); a thickly-coated mode is seen to develop during the transport process. Bottom panels show a 1-day-old air mass measured on $18 \mathrm{March}$ at $22.2^{\circ} \mathrm{N}$ at $3.5-3.8 \mathrm{~km}$ m.s.1. (d), 2-day-old air mass above this plume at $4.1 \mathrm{~km}$ m.s.l. (e), and 2-day-old Mexico City aerosol on 19 March off the Texas coast (f). Note that the color scales are different for each panel.

the same air mass on consecutive days should provide better insight into the evolution of $\mathrm{BC}$ during atmospheric transport. Further, instead of focusing on just one narrow BC mass range, we look at the entire range of $\mathrm{BC}$ masses (as the mass-equivalent diameter, MED) measured by the SP2. Figure 12 shows the BC mixing state for different air masses sampled on the 18 and 19 March flights, with incandescence lag on the $y$-axis and BC MED on the x-axis; the color corresponds to $\mathrm{BC}$ number concentration. As explained earlier, zero incandescence lag (or close to zero) indicates thinlycoated BC, while thickly-coated BC show an incandescence lag greater than $2 \mu \mathrm{s}$.

Figure 12a, b show fresh emissions sampled over Mexico City (T0) and over T2, while Fig. 12c shows the same air mass sampled a day later at $24.25^{\circ} \mathrm{N}$. Two interesting features are seen in these plots. First, the fresh emissions over T0 appear to be unimodal, with most BC particles showing almost-zero incandescent lag, i.e. the BC is thinly-coated. The MED peaks around $150 \mathrm{~nm}$ for this mode. As the air mass moves toward $\mathrm{T} 2$, we see more particles at larger incandescent lags closer to $4 \mu \mathrm{s}-$ thickly-coated BC. One day later, the thickly-coated $\mathrm{BC}$ mode is clearly seen, even though the thinly-coated $\mathrm{BC}$ mode still dominates.

Figure $12 \mathrm{~d}$ shows 1-day-old aerosol sampled on 18 March between $3.5 \mathrm{~km}-3.8 \mathrm{~km}$ m.s.l., Fig. 12e shows 2-day-old aerosol sampled at $4.1 \mathrm{~km}$ m.s.l. also on 18 March and Fig. 12f, 2-day-old Mexico City outflow intercepted off the Texas coast on 19 March (possibly the 1-day-old aerosol seen on $18 \mathrm{March}$ ). The 1-day-old aerosol sampled on 18 March between $3.5-3.8 \mathrm{~km}$ m.s.l. shows similar characteristics as the similarly-aged 19 March airmass (Fig. 12c), with similar MED size distributions and the presence of both thinlycoated and thickly-coated BC, though the thickly-coated BC mode dominates. In the 2-day-old aerosol at $4.1 \mathrm{~km} \mathrm{~m}$.s.l. (Fig. 12e), the thickly-coated BC mode is almost as prominent as the thinly-coated BC mode; however, the two-day-old air mass on 19 March (Fig. 12f) shows a more dispersed distribution and even appears to have more thinly-coated BC. 

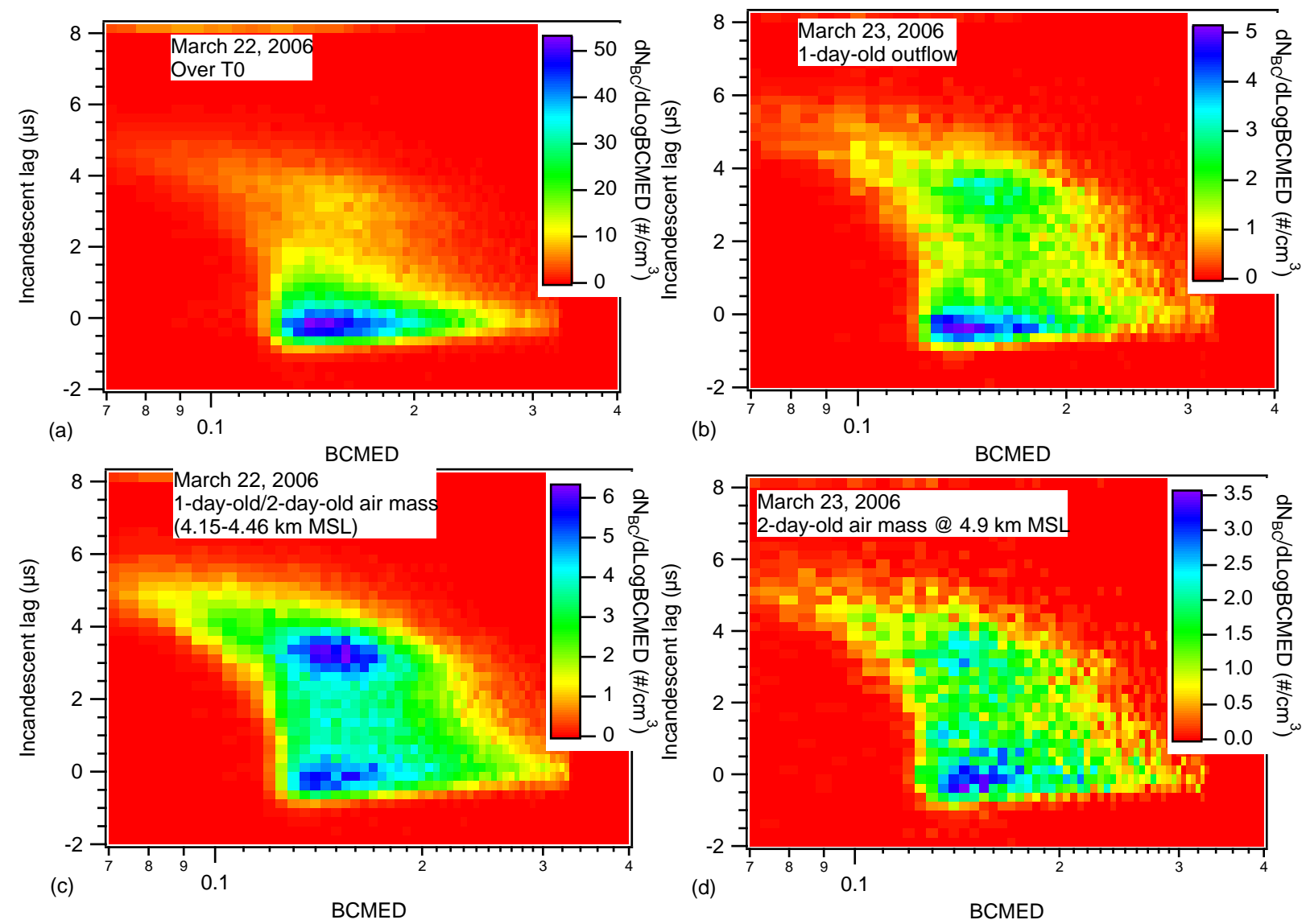

Fig. 13. BC mixing state spectra for the air masses sampled on 22 and 23 March. Fresh emissions measured over T0 on 22 March (a); 1-day-old Mexico City outflow over the Gulf of Mexico on 23 March (b); a mixture of 1-day-old and (more likely) 2-day-old air mass sampled on 22 March off Nautla (c); and 2-day-old Mexico City aerosol on 23 March over the Yucatan (d). Note that the color scales are different for each panel.

Thus, apart from the usual dilution process that reduces BC concentrations as the air mass ages and affects all plumes, we see an increase in the fraction of thickly-coated BC for the 1day-old aerosol on both days and the 2-day-old air mass on 18 March.

Figure 13 compares the 22 and 23 March data. Fresh emissions sampled over T0 on 22 March (Fig. 13a) show a prominent BC mode centered around $170 \mathrm{~nm}$ MED with incandescence lag close to zero, i.e. thinly-coated BC. The 1-dayold outflow on March 23 over the Gulf of Mexico (Fig. 13b) shows a second, but not as prominent, mode in the same diameter range but with an incandescence lag between 3-4 $\mu \mathrm{s}$, i.e. thickly-coated BC. The 2-day-old aerosol sampled on 22 March off Nautla (Fig. 13c, around 18:00 UTC) is dominated by thickly-coated BC; a similar pattern is seen in the sample taken around 21:30 UTC in the same area (not shown). However, the thickly-coated $\mathrm{BC}$ mode appears less prominent in the 2-day-old plume sampled over the Yucatan (Fig. 13d) around 19:00 UTC, while the later Yucatan sample (20:3420:48 UTC) shows depletion in both modes (not shown).

\section{Discussions and conclusion}

\subsection{Carbon monoxide and $\mathrm{BC}$}

Dickerson et al. (2002) find a $\mathrm{BC} / \mathrm{CO}$ ratio of $12.5 \mathrm{ng}$ $\mathrm{BC} / \mu \mathrm{g}-\mathrm{CO}$ measured on board the $\mathrm{R} / \mathrm{V}$ Ronald $\mathrm{H}$. Brown and a $\mathrm{BC} / \mathrm{CO}$ ratio of $27 \mathrm{ng}-\mathrm{BC} / \mu \mathrm{g}-\mathrm{CO}$ in the free troposphere as measured on board the C-130 aircraft in 1999 during INDOEX (these values are the slopes, which effectively removes background $\mathrm{CO}$ as the intercept), which are both higher than our measurements on the MIRAGE flights. Kondo et al. (2006) measured $\Delta \mathrm{EC} / \Delta \mathrm{CO}$ ratios of $\sim 6$ $\left(\mathrm{ng} / \mathrm{m}^{3}\right) / \mathrm{ppbv}$ (reported at ambient conditions) in Japan, and found this to be at the higher end compared to previouslyreported surface measurements, which ranged from 0.88 in Mexico City (Baumgardner et al., 2002) to 4.1 in Fort Meade, USA (Chen et al., 2001). (It should be noted though that the data presented and tabulated by Kondo et al. (2006) involve either light absorption or thermal-optical techniques for measuring $\mathrm{BC} / \mathrm{EC}$.) A more recent study by Baumgardner 
et al. (2007) using an SP2 at a ground site in Mexico City suggests the $\mathrm{BC} / \mathrm{CO}$ ratio is approximately $1 \mathrm{ng} / \mu \mathrm{g}$. Thus, our airborne $\mathrm{BC} / \mathrm{CO}_{\text {net }}$ ratios of $2.89\left(\mathrm{ng} / \mathrm{m}^{3}-\mathrm{STP}\right) / \mathrm{ppbv}$ or $\sim 2.3 \mathrm{ng} / \mu \mathrm{g}$, corrected to near-surface STP conditions, are similar to these surface measurements, though higher than the Baumgardner et al. (2007) SP2 measurements in Mexico City. One possible reason for this discrepancy is that the Baumgardner et al. (2007) measurements were close to vehicular traffic, while the C130 measurements include other source contributions, particularly mountain fires, which influence the aerosol and gas-phase pollutants measured over Mexico City (Yokelson et al., 2007). One explanation for the lower $\mathrm{BC} / \mathrm{CO}$ ratios over Mexico compared to the INDOEX data is that the source mix may be different between the Indian subcontinent and Mexico. Baumgardner et al. (2002) suggest that operating conditions including the altitude can also affect the $\mathrm{BC} / \mathrm{CO}$ ratio.

The background $\mathrm{CO}$ measured on the MIRAGE flights (62-67 ppbv or $76-83 \mu \mathrm{g} / \mathrm{m}^{3}$-STP) is almost a factor-of-two lower than Dickerson et al.'s aircraft-measured background $\mathrm{CO}\left(138 \mu \mathrm{g} / \mathrm{m}^{3}\right)$ over the Indian Ocean. However, our estimates compare favorably with the MOPITT (http://web.eos. ucar.edu/mopitt/) monthly averaged data at 850 mbar for the Pacific Ocean just west of Mexico, which suggests a $\mathrm{CO}$ background of about 80 ppbv in March/April 2006 (after correcting for a $20 \%$ bias, Emmons et al., 2009).

The lower CO background over Mexico may be due to lower gross emissions of $\mathrm{CO}$ from Mexico compared to emissions from the Indian subcontinent. Dickerson et al. estimate that in 1999, CO emissions from India were $67 \mathrm{Tg}-\mathrm{CO} / \mathrm{yr}$, including $15 \mathrm{Tg}-\mathrm{CO} / \mathrm{yr}$ from fossil fuel combustion and 40 $\mathrm{Tg}-\mathrm{CO} / \mathrm{yr}$ from biomass burning. Jiang et al. (2005) estimate that vehicular $\mathrm{CO}$ emissions (almost all of $\mathrm{CO}$ ) from Mexico City in 2002 were $1.2 \mathrm{Tg}-\mathrm{CO} / \mathrm{yr}$ in 2003. A 1999 Mexico National Emissions Inventory (SEMARNAT 2006) suggests nation-wide $\mathrm{CO}$ emissions of $7.5 \mathrm{Tg}-\mathrm{CO} / \mathrm{yr}$. Though neither of these studies is for the 2006 period (when MIRAGE was conducted), it is clear that $\mathrm{CO}$ emissions from Mexico are almost an order of magnitude lower than those from India. However, the background $\mathrm{CO}$ depends not just on the gross emissions, but also the flux at the point of measurement; such calculations are beyond the scope of this study.

\subsection{BC mixing state and mass absorption cross-section (MAC)}

Our measurements of the $\mathrm{BC}$ absorption cross-section, about $10.9 \mathrm{~m}^{2} / \mathrm{g} @ 660 \mathrm{~nm}$, translate to $13.1 \mathrm{~m}^{2} / \mathrm{g} @ 550 \mathrm{~nm}$ assuming a $\lambda^{-1}$ dependence. This is higher than the median values of $\sim 9 \mathrm{~m}^{2} / \mathrm{g} @ 550 \mathrm{~nm}$ reported by Doran (2007) at T1 (using a thermal-optical OC/EC analyzer and a photoacoustic absorption spectrometer, PAS) and 2.6 times the MAC values calculated by Baumgardner et al. (2007) near a bus terminal in Mexico City, using BC measurements with an SP2 and Mie theory. The Baumgardner et al. data may be biased low as the optical particle diameter used to estimate MAC of coated BC in their Mie calculations did not account for volatilization of the non-refractory coating described by Gao et al. (2007); there could be other reasons as well. However, the SP2/PSAP-based MAC in the present study is at the upper limit, $13.1 \mathrm{~m}^{2} / \mathrm{g} @ 550 \mathrm{~nm}$, of the range suggested by Bond and Bergstrom (2006) $\left(7.5 \pm 1.2 \mathrm{~m}^{2} / \mathrm{g} @ 550 \mathrm{~nm}\right)$, after accounting for the $50 \%$ enhancement suggested as representative of aged aerosol (Bond et al., 2006).

The SP2 data show that BC over Mexico City is dominated by the thinly-coated mode, which means that the $\mathrm{BC}$ MAC values we measured over Mexico City/T2, averaging $10.4-13.9 \mathrm{~m}^{2} / \mathrm{g} @ 660 \mathrm{~nm}$ (Table 1), are biased high compared to the Bond and Bergstrom (2006) value of $6.3 \mathrm{~m}^{2} / \mathrm{g}$ @ $660 \mathrm{~nm}$ for fresh/thinly-coated BC. This could occur if the SP2 collection efficiency for BC masses below 3 fg-BC (which might be more prominent in fresh emissions rather than coagulated older aerosol) is overestimated by our BC mass scaling factor, or if the PSAP absorption is biased high.

The PSAP data was corrected using the results of Virkkula et al. (2005); using the Bond et al. (1999) corrections would further increase the absorption and the derived MAC. A positive bias in the as-presented data can be caused by liquid organic matter coating the PSAP filter (Subramanian et al., 2007; Cappa et al., 2008; Lack et al., 2008), which would result in our MAC values being higher than actual. This potential bias in the PSAP absorption measurements onboard the $\mathrm{C}-130$ depends on the relative amounts of non-absorbing organic matter and BC (Lack et al., 2008) (and would not affect the PAS, which Doran used). From DeCarlo et al. (2008), the average organic aerosol concentration over Mexico City during MIRAGE was $\sim 16 \mu \mathrm{g} / \mathrm{m}^{3}$. The empirical studies by Lack et al. (2008) suggest that in such conditions, the PSAP could measure as much as $40-70 \%$ higher absorption. A positive bias of $50 \%$ in the PSAP data over Mexico City would bring the $\mathrm{BC}$ mass absorption cross-section into better agreement with the MAC values for fresh soot found by Bond and Bergstrom (2006) in their review.

If the PSAP data are biased high over Mexico City, is there a similar artifact in aged air masses? Our average MAC values in the older plumes with more thickly-coated BC are between 10.3-12.5 $\mathrm{m}^{2} / \mathrm{g} @ 660 \mathrm{~nm}$ (Table 1), except for one plume with $15.1 \mathrm{~m}^{2} / \mathrm{g}$. These numbers are at the Bond and Bergstrom (2006) upper limit for aged/thickly-coated BC, $10.9 \mathrm{~m}^{2} / \mathrm{g} @ 660 \mathrm{~nm}$. This suggests that the PSAP artifact may not be as significant in aged air masses with thicklycoated BC. One possible explanation is that liquid-phase biomass smoke and/or secondary organic aerosol (SOA) create an artifact in the PSAP absorption measurements while mixed externally with the city emissions over MCMA, while light absorption by thinly-coated $\mathrm{BC}$ remains unchanged. As the air masses mix further during transport away from MCMA, the liquid organic matter coagulates with morerefractory $\mathrm{BC}$ to form thickly-coated $\mathrm{BC}$ that has higher inherent light absorption as expected for aged BC (separate 
from artifacts in absorption measurement). The initial PSAP artifact, measured by Lack et al. (2008) as $40-70 \%$ higher absorption, is similar in magnitude to the enhancement due to coating during aging, suggested by Bond et al. (2006) as $\sim 50 \%$. Hence, even if there is an artifact due to externallymixed liquid organic matter on the PSAP data in aged aerosol, we cannot distinguish it from the aging-related MAC enhancement given the $\pm 30 \%$ measurement uncertainty on our MAC values. Both the SP2 measurement efficiency at smaller BC masses, particularly for fresh emissions, as well as PSAP response to organic matter of different ages and in different mixing states, need further research to resolve these discrepancies.

The SP2 data, Figs. 12 and 13, show that as the aerosol mass ages, the BC becomes thickly coated. When comparing just one narrow mass range of $\mathrm{BC}(\sim 180 \mathrm{~nm}$ MED) as Moteki et al. (2007) did, we did not see as great a change in the fraction of $\mathrm{BC}$ that is thickly-coated as Moteki et al. (2007) did. Broadening our perspective to the entire range of $\mathrm{BC}$ mass measured by the SP2, we see distinct patterns in the coating thickness and mass size distribution of $\mathrm{BC}$ particles as indicated by the incandescent lag measurements. Fresh emissions show mostly thinlycoated $\mathrm{BC}$ particles. As the air mass ages, we find a more prominent mode of thickly-coated $\mathrm{BC}$, seen to a greater extent with the 2-day-old outflows at $4.1 \mathrm{~km}$ m.s.1./22. $2^{\circ} \mathrm{N}$ on 18 March and off Nautla on 22 March. The 2-dayold air masses sampled on 19 March off the Texas coast and on 23 March over the Yucatan did not show a thicklycoated BC mode. It is possible that the likely-hydrophilic thickly-coated BC mode gets preferentially wet-scavenged. MODIS satellite images (http://rapidfire.sci.gsfc.nasa.gov/ subsets/?subset=SERVIR_Mexico) taken on 23 March show rain clouds over the Gulf of Mexico, which suggests such a possibility for the 2-day-old aerosol over the Yucatan.

These data suggest that depending on which processes are more dominant over the life of the aerosol, BC concentrations and coating thicknesses may differ during atmospheric transport even if the sources are the same. Further, the concentrations and coating characteristics may end up looking similar during later stages of the aerosol lifetime. This means that the overall lifetime effect of $\mathrm{BC}$ on radiative forcing may not be the same for emissions from the same source even for emissions just a few days apart. However, it could be argued that such variations average out over time, but this needs more study.
Acknowledgements. The C130 SP2 measurements were funded by the National Science Foundation under grant \#0511780. The WRF modeling work was supported by NSF grant \#ATM0810950, while the CMET balloon work was made possible by NSF grant \#ATM0511833-0022095000. The authors gratefully acknowledge the NOAA Air Resources Laboratory (ARL) for the provision of the HYSPLIT transport and dispersion model and/or READY website (http://www.arl.noaa.gov/ready.html) used in this publication.

Edited by: S. Madronich

\section{References}

Baumgardner, D., Kok, G. L., and Raga, G. B.: On the diurnal variability of particle properties related to light absorbing carbon in Mexico City, Atmos. Chem. Phys., 7, 2517-2526, 2007.

Baumgardner, D., Raga, G. B., Peralta, O., Rosas, I., Castro, T., Kuhlbusch, T., John, A., and Petzold, A.: Diagnosing black carbon trends in large urban areas using carbon monoxide measurements, J. Geophys. Res.-Atmos., 107(D21), 8342, doi:10.1029/2001JD000626, 2002.

Bond, T. C.: Can warming particles enter global climate discussions?, Environ. Res. Lett., 2, 045030, doi:10.1088/17489326/2/4/045030, 2007.

Bond, T. C., Anderson, T. L., and Campbell, D.: Calibration and intercomparison of filter-based measurements of visible light absorption by aerosols, Aerosol Sci. Technol., 30(6), 582-600, 1999.

Bond, T. C. and Bergstrom, R. W.: Light absorption by carbonaceous particles: An investigative review, Aerosol Sci. Technol., 40(1), 27-67, 2006.

Bond, T. C., Habib, G., and Bergstrom, R. W.: Limitations in the enhancement of visible light absorption due to mixing state, J. Geophys. Res.-Atmos., 111(D20), D20211, doi:10.1029/2006JD007315, 2006.

Cappa, C. D., Lack, D. A., Burkholder, J. B., and Ravishankara, A. R.: Bias in filter based aerosol light absorption measurements due to organic aerosol loading: Evidence from laboratory measurements, Aerosol Sci. Technol. 42(12), 1022-1032, 2008.

Chen, L.-W. A., Doddridge, B. G., Dickerson, R. R., Chow, J. C., Mueller, P. K., Quinn, J., and Butler, W. A.: Seasonal variations in elemental carbon aerosol, carbon monoxide and sulfur dioxide: Implications for sources, Geophys. Res. Lett. 28, 17111714, 2001.

Chow, J. C., Watson, J. G., Crow, D., Lowenthal, D. H., and Merrifield, T.: Comparison of IMPROVE and NIOSH carbon measurements, Aerosol Sci. Technol., 34(1), 23-34, 2001.

DeCarlo, P. F., Dunlea, E. J., Kimmel, J. R., Aiken, A. C., Sueper, D., Crounse, J., Wennberg, P. O., Emmons, L. K., Shinozuka, Y., Clarke, A., Zhou, J., Tomlinson, J., Collins, D. R., Knapp, D., Weinheimer, A. J., Montzka, D. D., Campos, T. L., and Jimenez, J. L.: Fast airborne aerosol size and chemistry measurements above Mexico City and Central Mexico during the MILAGRO campaign, Atmos. Chem. Phys., 8, 4027-4048, 2008.

de Foy, B., Zavala, M., Bei, N. F., and Molina, L. T.: Evaluation of WRF mesoscale simulations and particle trajectory analysis for the MILAGRO field campaign, Atmos. Chem. Phys., 9, 44194438, 2009a. 
de Foy, B., Wood, E. C., Herndon, S. C., Ruiz-Suarez, L. G., Martinez, A.-P., Huey, L. G., Bei, N. F., Zavala, M., and Molina, L. T.: Hit from both sides: tracking industrial and volcanic plumes in Mexico City with surface measurements and OMI SO2 retrievals during the MILAGRO field campaign, Atmos. Chem. Phys. Discuss., 9, 16563-16605, 2009b.

Dickerson, R. R., M. O. Andreae, T. L. Campos, O. L. MayolBracero, C. Neusuess and D. G. Streets: Analysis of black carbon and carbon monoxide observed over the Indian Ocean: Implications for emissions and photochemistry, J. Geophys. Res.Atmos., 107(D19), 8017, doi:10.1029/2001JD000501, 2002.

Doran, C.: Corrigendum to "The T1-T2 study: evolution of aerosol properties downwind of Mexico City", Atmos. Chem. Phys., 7, 2197-2198, 2007, http://www.atmos-chem-phys.net/7/2197/2007/.

Doran, J. C., Fast, J. D., Barnard, J. C., Laskin, A., Desyaterik, Y., and Gilles, M. K.: Applications of lagrangian dispersion modeling to the analysis of changes in the specific absorption of elemental carbon, Atmos. Chem. Phys., 8, 1377-1389, 2008.

Draxler, R. R. and Rolph, G. D.: HYSPLIT (HYbrid Single-Particle Lagrangian Integrated Trajectory) Model access via NOAA ARL READY Website (http://www.arl.noaa.gov/ready/hysplit4.html), NOAA Air Resources Laboratory, Silver Spring, MD, USA, 2003.

Emmons, L. K., Edwards, D. P., Deeter, M. N., Gille, J. C., Campos, T. L., Nedelec, P., Novelli, P., and Sachse, G.: Measurements of Pollution In The Troposphere (MOPITT) validation through 2006, Atmos. Chem. Phys., 9, 1795-1803, 2009, http://www.atmos-chem-phys.net/9/1795/2009/.

Fast, J. D., de Foy, B., Acevedo Rosas, F., Caetano, E., Carmichael, G. R., Emmons, L. K., McKenna, D., Mena, M., Skamarock, W., Tie, X., Coulter, R. L., Barnard, J. C., Wiedinmyer, C., and Madronich, S.: A meteorological overview of the MILAGRO field campaigns, Atmos. Chem. Phys., 7, 2233-2257, 2007.

Fast, J. D. and Easter, R.: A Lagrangian Particle Dispersion Model Compatible with WRF, in: 7th WRF User's Workshop, Boulder, CO, USA, 2006.

Gao, R. S., Schwarz, J. P., Kelly, K. K., Fahey, D. W., Watts, L. A., Thompson, T. L., Spackman, J. R., Slowik, J. G., Cross, E. S., Han, J.-H., Davidovits, P., Onasch, T. B., and Worsnop, D. R.: A novel method for estimating lightscattering properties of soot aerosols using a modified singleparticle soot photometer, Aerosol Sci. Technol., 41(2), 125-135, doi:10.1080/02786820601118398, 2007.

Gerbig, C., Schmitgen, S., Kley, D., Volz-Thomas, A., Dewey, K., and Haaks, D.: An improved fast-response vacuum-UV resonance fluorescence CO instrument, J. Geophys. Res.-Atmos., 104, 1699-1704, 1999.

Jacobson, M. Z.: Control of fossil-fuel particulate black carbon and organic matter, possibly the most effective method of slowing global warming, J. Geophys. Res.-Atmos., 107(D19), 4410, doi:10.1029/2001JD001376, 2002.

Jiang, M., Marr, L. C., Dunlea, E. J., Herndon, S. C., Jayne, J. T., Kolb, C. E., Knighton, W. B., Rogers, T. M., Zavala, M., Molina, L. T., and Molina, M. J.: Vehicle fleet emissions of black carbon, polycyclic aromatic hydrocarbons, and other pollutants measured by a mobile laboratory in Mexico City, Atmos. Chem. Phys., 5, 3377-3387, 2005.
Johnson, K. S., Zuberi, B., Molina, L. T., Molina, M. J., Iedema, M. J., Cowin, J. P., Gaspar, D. J., Wang, C., and Laskin, A.: Processing of soot in an urban environment: case study from the Mexico City Metropolitan Area, Atmos. Chem. Phys., 5, 30333043, 2005.

Khalili, M. A. K. and Rasmussen, R. A.: The global cycle of carbon monoxide: trends and mass balance, Chemosphere, 20(1-2), 227-242, 1990.

Kirchstetter, T. W., Harley, R. A., Kreisberg, N. M., Stolzenburg M. R., and Hering, V. S.: On-road measurement of fine particle and nitrogen oxide emissions from light- and heavy-duty motor vehicles, Atmos. Environ. 33, 2955-2968, 1999.

Kondo, Y., Komazaki, Y., Miyazaki, Y., Moteki, N., Takegawa, N., Kodama, D., Deguchi, S., Nogami, M., Fukuda, M., Miyakawa, T., Morino, Y., Koike, M., Sakurai, H., and Ehara, K.: Temporal variations of elemental carbon in Tokyo, J. Geophys. Res.Atmos., 111, D12205, doi:10.1029/2005JD006257, 2006.

Lack, D. A., Cappa, C. D., Covert, D. S., Baynard, T., Massoli, P., Sierau, B., Bates, T. S., Quinn, P. K., Lovejoy, E. R., and Ravishankara, A. R.: Bias in filter-based aerosol light absorption measurements due to organic aerosol loading: Evidence from ambient measurements, Aerosol Sci. Technol., 42(12), 1033-1041, 2008.

Levy, H., Schwarzkopf, M. D., Horowitz, L., Ramaswamy, V., and Findell, K. L.: Strong sensitivity of late 21 st century climate to projected changes in short-lived air pollutants, J. Geophys. Res.Atmos., 113, D06102, doi:10.1029/2007JD009176, 2008.

Molina, L. T., Madronich, S., Gaffney, J. S., et al.: An overview of the MILAGRO campaign: Mexico City emissions and their evolution, in preparation, 2010.

Moteki, N. and Kondo, Y.: Effects of mixing state on black carbon measurements by laser-induced incandescence, Aerosol Sci. Technol., 41(4), 398-417, doi:10.1080/02786820701199728, 2007.

Moteki, N., Kondo, Y., Miyazaki, Y., Takegawa, N., Komazaki, Y., Kurata, G., Shirai, T., Blake, D. R., Miyakawa, T., and Koike, M.: Evolution of mixing state of black carbon particles: Aircraft measurements over the western Pacific in March 2004, Geophys. Res. Lett., 34, L11803, doi:10.1029/2006GL028943, 2007.

Ogren, J. A. and Charlson, R. J.: Elemental carbon in the atmosphere - Cycle and lifetime, Tellus B, 35B, 241-254, 1983.

Reid, J. S., Koppmann, R., Eck, T. F., and Eleuterio, D. P.: A review of biomass burning emissions part II: intensive physical properties of biomass burning particles, Atmos. Chem. Phys., 5, 799825,2005

Riddle, E. E., Voss, P. B., Stohl, A., Holcomb, D., Maczka, D., Washburn, K., and Talbot, R. W.: Trajectory model validation using newly developed altitude-controlled balloons during the International Consortium for Atmospheric Research on Transport and Transformations 2004 campaign, J. Geophys. Res., 111, D23S57, doi:10.1029/2006JD007456, 2006.

Rolph, G. D.: Real-time Environmental Applications and Display sYstem (READY) Website: http://www.arl.noaa.gov/ready/ hysplit4.html), NOAA Air Resources Laboratory, Silver Spring, MD, USA, 2003.

Rosen, H., Hansen, A. D. A., Gundel, L., and Novakov, T.: Identification of Optically Absorbing Component in Urban Aerosols, Appl. Optics, 17(24), 3859-3861, 1978. 
Schauer, J. J., Mader, B. T., Deminter, J. T., Heidemann, G., Bae, M. S., Seinfeld, J. H., Flagan, R. C., Cary, R. A., Smith, D., Huebert, B. J., Bertram, T., Howell, S., Kline, J. T., Quinn, P., Bates, T., Turpin, B., Lim, H. J., Yu, J. Z., Yang, H., and Keywood, M. D.: ACE-Asia intercomparison of a thermal-optical method for the determination of particle-phase organic and elemental carbon, Environ. Sci. Technol., 37(5), 993-1001, 2003.

Schmid, H., Laskus, L., Abraham, H. J., Baltensperger, U., Lavanchy, V., Bizjak, M., Burba, P., Cachier, H., Crow, D., Chow, J., Gnauk, T., Even, A., ten Brink, H. M., Giesen, K. P., Hitzenberger, R., Hueglin, E., Maenhaut, W., Pio, C., Carvalho, A., Putaud, J. P., Toom-Sauntry, D., and Puxbaum, H.: Results of the "carbon conference" international aerosol carbon round robin test stage I, Atmos. Environ. 35(12), 2111-2121, 2001.

Schwarz, J. P., Gao, R. S., Fahey, D. W., Thomson, D. S., Watts, L. A., Wilson, J. C., Reeves, J. M., Darbeheshti, M., Baumgardner, D. G., Kok, G. L., Chung, S. H., Schulz, M., Hendricks, J., Lauer, A., Karcher, B., Slowik, J. G., Rosenlof, K. H., Thompson, T. L., Langford, A. O., Loewenstein, M., and Aikin, K. C.: Single-particle measurements of midlatitude black carbon and light-scattering aerosols from the boundary layer to the lower stratosphere, J. Geophys. Res.-Atmos., 111(D16), D16207, doi:10.1029/2006JD007076, 2006.

SEMARNAT: Mexico National Emissions Inventory, 1999: Final, 2006.

Slowik, J. G., Cross, E. S., Han, J.-H., Davidovits, P., Onasch, T. B., Jayne, J. T., Williams, L. R., Canagaratna, M. R., Worsnop, D. R., Chakrabarty, R. K., Moosmuller, H., Arnott, W. P., Schwarz, J. P., Gao, R. S., Fahey, D. W., Kok, G. L., and Petzold, A.: An inter-comparison of instruments measuring black carbon content of soot particles, Aerosol Sci. Technol., 41(3), 295-314, doi:10.1080/02786820701197078, 2007.

Skamarock, W. C., Klemp, J. B., Dudhia, J., Gill, D. O., Barker, D. M., Wang, W., and Powers, J. G.: A Description of the Advanced Research WRF Version 2, Tech. Rep. NCAR/TN-20 468+STR, NCAR, 2005.

Stephens, M., Turner, N., and Sandberg, J.: Particle identification by laser-induced incandescence in a solid-state laser cavity, Appl. Optics, 42(19), 3726-3736, 2003.
Stohl, A., Forster, C., Frank, A., Seibert, P., and Wotawa, G.: Technical note: The Lagrangian particle dispersion model FLEXPART version 6.2, Atmos. Chem. Phys., 5, 2461-2474,2005.

Subramanian, R., Donahue, N. M., Bernardo-Bricker, A., Rogge, W. F., and Robinson, A. L.: Contribution of motor vehicle emissions to organic carbon and fine particle mass in Pittsburgh, Pennsylvania: Effects of varying source profiles and seasonal trends in ambient marker concentrations, Atmos. Environ., 40(40), 8002-8019, 2006a.

Subramanian, R., Khlystov, A. Y., and Robinson, A. L.: Effect of peak inert-mode temperature on Elemental Carbon measured using Thermal-Optical analysis, Aerosol Sci. Technol., 40(10), 763-780, 2006b.

Subramanian, R., Roden, C. A., Boparai, P., and Bond, T. C.: Yellow beads and missing particles: Trouble ahead for filter-based absorption measurements, Aerosol Sci. Technol., 41(6), 630637, 2007.

Sun, H., Biedermann, L., and Bond, T. C.: Color of brown carbon: A model for ultraviolet and visible light absorption by organic carbon aerosol, Geophys. Res. Lett., 34, L17813, doi:10.1029/2007GL029797, 2007.

Virkkula, A., Ahlquist, N. C., Covert, D. S., Arnott, W. P., Sheridan, P. J., Quinn, P. K., and Coffman, D. J.: Modification, calibration and a field test of an instrument for measuring light absorption by particles, Aerosol Sci. Technol. 39(1), 68-83, 2005.

Voss, P. B., Riddle, E. E., and Smith, M. S.: Altitude control of long-duration balloons, J. Aircraft, 42(2), 478-482, 2005.

Voss, P. B., Zaveri, R. A., Hartley, T., Deonandan, I., DeAmicis, P., Antonio, O. M., Jiménez, G. C., Greenberg, D., Estrada, M., Flocke, F., Madronich, S., Kleinman, L. I., Springston, S. R., Hubbe, J., de Foy, B., and Mao, H.: Measurement of Transport and Dispersion of the 18-19 March Mexico City Outflow Event using Long-Duration Altitude-Controlled Balloons, in preparation, 2010.

Yokelson, R. J., Urbanski, S. P., Atlas, E. L., Toohey, D. W., Alvarado, E. C., Crounse, J. D., Wennberg, P. O., Fisher, M. E., Wold, C. E., Campos, T. L., Adachi, K., Buseck, P. R., and Hao, W. M.: Emissions from forest fires near Mexico City, Atmos. Chem. Phys., 7, 5569-5584, 2007. 